This item was submitted to Loughborough's Research Repository by the author.

Items in Figshare are protected by copyright, with all rights reserved, unless otherwise indicated.

\title{
Assessing abnormal returns: the case of Chinese M\&A acquiring firms
}

PLEASE CITE THE PUBLISHED VERSION

http://dx.doi.org/10.1016/j.ribaf.2017.05.009

PUBLISHER

(c) Elsevier

VERSION

AM (Accepted Manuscript)

\section{PUBLISHER STATEMENT}

This work is made available according to the conditions of the Creative Commons Attribution-NonCommercialNoDerivatives 4.0 International (CC BY-NC-ND 4.0) licence. Full details of this licence are available at: https://creativecommons.org/licenses/by-nc-nd/4.0/

\section{LICENCE}

CC BY-NC-ND 4.0

\section{REPOSITORY RECORD}

Song, Xiaojing, Mark J. Tippett, and Andrew Vivian. 2019. "Assessing Abnormal Returns: The Case of Chinese M\&A Acquiring Firms". figshare. https://hdl.handle.net/2134/26037. 


\section{ASSESSING ABNORMAL RETURNS: THE CASE OF CHINESE M\&A ACQUIRING FIRMS}

\section{Introduction}

Merger and acquisition (M\&A) activity in China has increased dramatically over the last 15 years. This is due amongst other reasons to the remarkable growth rate in China's economic output as well as China's admission to the World Trade Organisation (WTO) in 2001. However, research conducted into the area of Chinese $M \& A$ activities remains relatively sparse. Moreover, such research as has been conducted on Chinese M\&A activities is generally discursive and is not based on rigorous statistical analysis. This paper provides more concrete empirical evidence of the impact that Chinese M\&A activities have on the shareholders of acquiring firms by examining the returns of 279 randomly selected Chinese acquiring firms covering the period from 1990 until 2008. We also contrast our empirical results with those obtained in the prior literature for western economies in order that we might identify the underlying reasons for the differences which exist between the wealth effects of Chinese and western M\&A activities. Here it is important to note that there are significant institutional differences between China and western countries which make it less likely that Chinese companies will overpay for target firms; firstly, all companies have state-owned shares on issue and in the event of a takeover the consideration for these shares is based on book rather than their market value and secondly, all deals have to receive regulatory approval before they are publicly announced and this greatly reduces the prospect of a bidding war for the target company.

Furthermore, this paper analyses the impact of employing different modes of consideration (that is, payment methods) on Chinese acquiring firms both in terms of the average abnormal returns (AARs) and the cumulative average abnormal returns (CAARs) using a 24-day event window surrounding the takeover announcement date. We also identify potential reasons for the differing economic benefits that appear to arise from using cash as against 
alternative modes of consideration ${ }^{1}$ for the shareholders of Chinese acquiring firms. Finally, we test if the pre-takeover stock values of acquiring firms have any relationship with the modes of consideration chosen to finance Chinese M\&A activities. When there are informational asymmetries ${ }^{2}$ and a company is highly valued then the acquirer has an incentive to use alternative modes of consideration to pure cash (Hansen 1987). This enables the acquiring company to i) reduce the cost of takeover by issuing new shares at a low expected return (high price) and ii) transfer some of the risk associated with the deal to the target shareholders which benefits the acquirer's shareholders.

Our study makes three principal contributions to the M\&A literature: i) Chinese acquirers overall have positive abnormal returns surrounding the takeover announcement date. This is in contrast with the vast majority of prior western literature which reports negligible and often negative benefits for acquiring firms (Martynova and Renneboog, 2008); ii) Alternative modes of consideration have higher abnormal returns than cash deals. This also contrasts with the prior western literature where cash deals tend to have higher CAARs than non-cash deals (Martynova and Renneboog, 2008) ; iii) Finally, and consistent with the model of Hansen (1987), we find that in Chinese M\&A activities alternative modes of consideration only earn higher CAARs than cash deals when the acquiring firm's stock is highly valued.

\section{Summary of Prior Literature}

There is a voluminous western literature that examines wealth effects for $M \& A$ acquirers. In contrast, there is a relatively sparse literature ${ }^{3}$ that deals with the wealth effects of Chinese M\&A activities, much of which is theoretical (as

\footnotetext{
${ }^{1}$ The alternative modes of consideration are mainly comprised of the acquiring firm's stock. However, it may also consist of issuing convertible bonds in the acquiring firm, the issue of warrants by the acquiring firm, the transfer of some of the acquiring firm's assets to the shareholders of the target firm, the repayment of some of the target firm's debt by the acquiring firm or some combination of two or more of these alternative modes of consideration.

${ }^{2}$ In our sample there are informational asymmetries, for example most targets are unlisted firms.

${ }^{3}$ Since Chinese M\&A activities only commenced in the 1990s and especially after China's admission to WTO in 2001, the research conducted on Chinese M\&A activities is not as exhaustive as it is in developed countries like the US and the UK.
} 
distinct from empirical) in nature. Both the western empirical literature and such empirical evidence as is available on Chinese M\&A activities focuses on the pure wealth effects of $M \& A$ activities for the shareholders of acquiring firms. These empirical results are mixed and inconsistent on the central issue of whether acquiring firm shareholders obtain abnormal returns that are statistically different from zero; irrespective of whether one is dealing with the voluminous western literature or the relatively sparse Chinese literature.

For example, Dodd and Ruback (1977) employ a sample of 172 U.S. acquiring firms covering the period from 1958 until 1976 and find that stockholders of successful bidding (that is, acquiring) firms earn positive abnormal returns in the month of the takeover announcement. However, Asquith (1983) finds that the stock market shows little or no reaction on the date of the first public announcement of the merger and/or acquisition proposal and this applies for both successful and unsuccessful bidding firms. In contrast, Langtieg (1978) finds evidence of negative abnormal returns for acquiring firms over the six months before and twelve months after the acquisition date. Bruner (2003) undertakes an extensive literature review in this area and concludes that in aggregate, abnormal returns to shareholders' of acquiring firms from $M \& A$ activities are essentially zero.

There are very few papers which examine the impact that M\&A activities have on shareholder wealth for Chinese acquiring firms. And the few papers that are available tend to focus on a narrow time period beginning in the mid to late 1990's before China was admitted to the WTO in 2001. Chen and Zhang (1999), for example, employ data for M\&A transactions on the Shanghai Stock Exchange covering the 1997 fiscal year. Using a standard market model methodology they find that the CAARs associated with acquiring firms remain insignificantly different from zero over the entire event window. Yu and Yang (2000) employ a sample comprised of all mergers and/or acquisitions which occurred on the two mainland Chinese (that is, the Shanghai and Shenzhen) stock exchanges over the period from 1993 until 1995. They also find that the CAARs associated with the acquiring firms comprising their sample randomly fluctuated around zero over their entire event window. In contrast, Li and 
Chen (2002) investigated the M\&A activities of firms listed on the Shanghai and Shenzhen stock exchanges over the period from 1999 to 2000 . They find that there are significant economic benefits for the shareholders of acquiring firms; in particular, the CAAR was a statistically significant $3 \%$ by the end of the 30-day post announcement event window used in their study. Hence, such empirical evidence as there is paints a mixed and somewhat inconsistent picture about the wealth effects that $M \& A$ activities have on the shareholders of Chinese acquiring firms. ${ }^{4}$

There is also a large volume of work in western countries as well as a growing literature in China that deals with the issue of whether the economic benefits obtained by Chinese acquiring firms hinge on the mode of consideration employed in their M\&A activities. Asquith, Bruner and Mullins (1990) is one of the early western studies that deals with the economic benefits which accrue to shareholders of acquiring firms under different payment methods. They employ a sample of 343 mergers listed on either the New York Stock Exchange (NYSE) or the American Stock Exchange (AMEX) over the period from 1975 until 1983. Their results indicate that both the abnormal percentage returns and the abnormal dollar returns for acquiring firms are smaller for stock financed takeovers in comparison to takeovers where the mode of consideration is solely in cash. These results are consistent with most of the western literature in the area which consistently finds that the economic benefits which accrue to the shareholders of acquiring firms are larger for takeovers where the consideration is in cash in comparison to takeovers where alternative modes of consideration are employed (Amihud et al., 1990; Servaes, 1991; Brown and Ryngaert, 1991). The one major exception is the paper by Yook (2003) which reports abnormal returns that are not statistically different between cash and stock acquisitions, although even here the magnitude of cash abnormal returns are still higher than stock deals. Yook (2003) also notes that there is some evidence that takeovers which turn out to be highly detrimental to shareholder wealth are more likely to be financed by the stock of the acquiring firm rather than in cash.

\footnotetext{
${ }^{4}$ From the literature summarised here we can see that very few studies examine takeover activities in China over a period of more than 2 years. We address this issue by analysing Chinese M\&A activities over the much longer period from 1990 until 2008.
} 
There is also a small Chinese literature that addresses the issue of whether the economic benefits to shareholders of acquiring firms where the takeover consideration is solely in cash exceed the benefits which arise when the consideration is other than purely in cash. However, the empirical work summarised in this literature reports inconsistent and often contradictory results. For example, using a sample of 96 acquisitions that occurred in China in 2006, Ge and Ping (2009) conclude that non-cash takeovers, which are principally comprised of share swap transactions, have positive wealth enhancing effects for the shareholders of Chinese acquiring firms over the short term; in contrast, cash based takeovers do not have significant wealth enhancing effects for the shareholders of Chinese acquiring firms. Zhang, Wang and Meng (2007) also note that using cash as the sole mode of consideration for Chinese M\&A activities can lead to Chinese acquiring firms securing pre-emptive rights in the form of a quick takeover. They note that this is the reason why in hostile tender offers especially, cash is typically employed as the mode of consideration. Nevertheless the vast majority of Chinese deals are friendly. Zhang, Wang and Meng (2007) also note that most Chinese acquiring firms lack the free cash flows necessary for the internal financing of their M\&A activities through cash offers. They also note that when cash offers do occur it is normally the case that acquiring firms raise debt from banks and/or other financial institutions so that they can finance their M\&A activities through cash. Our study extends the sparse Chinese literature available in this area by i) conducting a more robust empirical analysis using recently developed nonparametric statistical techniques (Ataullah et al., 2011) and ii) examining M\&A's that occur over the much longer time frame from 1990 until 2008, rather than just the one or two- year period that is typical of the pre-existing Chinese literature in the area. We also investigate whether the relative value of the acquiring firm's stock has any impact on the choice of the mode of consideration used to finance the takeover and on the CAARs earned by the acquiring firm as a result of the takeover as suggested in the model developed by Hansen (1987). Finally, we provide evidence on the extent to which results from studies of M\&A activities in developed countries like the U.S. and U.K. can be 
generalised to Chinese capital markets which have very different legal and institutional structures when compared to capital markets in the west.

\section{Institutional Background and Data}

We have previously noted how there are two stock exchanges in mainland China; namely, the Shanghai and Shenzhen stock exchanges. Moreover, "A" shares and "B" shares are the two categories of stock which are listed on both these exchanges. The principal focus of our empirical analysis is with the $A$ shares of Chinese acquiring firms since the market capitalisation of $B$ shares is consistently lower than $1 \%$ of the total capitalised value of tradable Ashares over the period covered by our empirical work (Ma 2014, 116) ${ }^{5}$.

Here we need to note that a unique feature of the mainland Chinese stock markets is that not all the A shares issued by firms are tradable, and this constitutes a significant difference from the stock markets in western countries like the USA and UK. A shares can be sub-divided into three groups which are "state owned" shares, "legal person" shares and "public individual" shares in terms of the strictly defined groups of shareholdings in China. State owned shares are those owned by the state, including the central and local governments. Legal person shares are those held by domestic legal entities and institutions such as state-private mixed enterprises and non-bank financial institutions (Qi and Wu, 2000). An important point that needs to be made here is that only public individual shares are freely tradable on mainland stock markets; that is, state owned shares and legal person shares cannot be traded on these markets. Moreover, non-tradable A shares (that is, state shares and legal person shares) account for a majority of the A shares issued by most listed firms before 2005 at which time the China Securities Regulation Committee $(\mathrm{CSRC})^{6}$ issued a new plan for shareholding structure reform

\footnotetext{
${ }^{5}$ Until recently, only foreign investors (including investors from Taiwan, Hong Kong and Macao) could purchase B shares. Whilst both the principal and dividends of $B$ shares are normally denominated in the RMB (Yuan), trading on the stock market in B shares normally occurs in either the US dollar or the Hong Kong dollar and not the Yuan.

${ }^{6}$ The CSRC is the main securities regulatory body in China and governs overall securities exchanges and futures markets activity within China. It includes more than 30 regulatory bureaus that cover different geographic regions of the country, and two supervisory bureaus at the nation's two largest stock exchanges in Shanghai and Shenzhen.
} 
called 'Guquan Fenzhi Gaige'. Under Guquan Fenzhi Gaige market-based processes are gradually being implemented for the transfer of share ownership rather than the government-imposed processes which had prevailed up until that point in time.

The Measures for the Administration of Takeovers of Listed Companies ${ }^{7}$ as promulgated by the CSRC in 2006, stipulate that when an acquiring firm makes a takeover offer for a listed target firm two offer prices must be set for the shares of the listed target firm. ${ }^{8}$ One offer price must be set for the tradable shares and another offer price must be set for the non-tradable shares in the listed target firm. The offer price for the tradable shares of the listed target firm is determined by reference to the market price of those shares on the stock exchange whilst the offer price for the non-tradable shares is based on the net asset (book) value of the target firm as summarised in its latest set of audited financial statements. Thus for these non-tradable shareholders the stock price is fixed when a takeover occurs and hence, the target firm has limited ability to negotiate or inflate its value. Finally, Article 28 of the Takeover Measures 2006 mandates that a takeover bid cannot be made public until the CSRC has been notified of the bid and can only be announced if no objections are raised by the CSRC. ${ }^{9}$ Given that regulatory approval is needed for a bid this limits the possibility of other interested parties counter-bidding for the target and thus again limits the ability for the target firm to inflate its value in the Chinese context.

Our empirical analysis is based on the definition of a takeover given in Article 84(1) of the Takeover Measures 2006. This article provides that a takeover occurs when an acquiring firm successfully purchases more than $50 \%$ of the equity shares of a listed target firm. Data on Chinese mergers and acquisitions were obtained from the Data Company Mergers and Acquisitions

\footnotetext{
7 We shall henceforth refer to the Measures for the Administration of Takeovers of Listed Companies as the Takeover Measures 2006.

8 See Song and Tippett (2013) for a detailed summary of the Takeover Measures (2006).

${ }^{9}$ The CSRC checks the bid is consistent with Chinese laws, administrative regulations and other related provisions.
} 
[SDC (M\&A)] Database. Over the period from 1 January, 1990 until 31 December, 2008 there were 2,448 cases on the SDC database where Chinese firms sought to acquire either a controlling or other interest in another firm. However, only a small proportion of these acquisitions satisfied the definition of a takeover in Article 84(1) of the Takeover Measures 2006. Given this, our empirical analysis is based on a random sample of $N=279$ Chinese firms involved in acquisitions that satisfied the provisions of Article 84(1) of the Takeover Measures 2006 and that also had the prices of their A share prices available on the Datastream database. ${ }^{10}$ Table 1 provides a summary of the industrial classifications and the years in which the acquisitions occurred for the $N=279$ acquiring firms on which our empirical analysis is based. Thus, for the Household Goods and Home Construction classification there were two takeovers in 2006, one takeover in 2007 and two takeovers in 2008 - that is, five takeovers in total. Data for the other industry classifications are to be similarly interpreted.

Note how Table 1 also shows that there were only a small number of takeovers before China was admitted to the World Trade Organisation (WTO) in 2001. There are two principal reasons for this. First, the Shanghai and Shenzhen stock exchanges were established in 1990 and 1991, respectively with only around 8 companies listed on each stock exchange. From these humble beginnings the number of traded stocks gradually increased to 646 for the Shanghai stock exchange in 2001 and 508 for the Shenzhen stock exchange. By 2015, these figures had grown to 1,081 for the Shanghai stock exchange and 1,746 for the Shenzhen stock exchange. Hence, the relatively small number of companies listed on the Shanghai and Shenzhen stock exchanges is the first factor contributing to the small number of mergers and acquisitions in China over the period from 1990 and 2001. A second factor relates to the political and economic reforms which were implemented by Chinese government between 1990 and 2004 and which led to an average

\footnotetext{
10 In an appendix to the paper (available from the authors on request) we use Cantelli's Inequality (Savage, 1961, p. 216) to show that this sample is more than sufficient to generalise the empirical results we obtain to the entire sample of takeovers that do satisfy the provisions of Article 84(1) of the Takeover Measures (2006).
} 
rate of growth in GNP in excess of $10 \%$ per annum over this period. ${ }^{11}$ Many of these reforms were made in the run up to China's admission to WTO in 2001 and led to a significant increase in the number of small privately owned companies. 12 However, a significant proportion of these small private companies were under capitalised and performed poorly due to inadequate financing. Acquiring these undercapitalised small private companies was a mechanism used by publicly listed companies to maintain the growth rates being demanded of them under the political and economic reforms which were being implemented by Chinese government at this time.

We also divide the $N=279$ Chinese acquiring firms comprising our sample into two categories. The first category is comprised of 168 acquiring firms where cash is the sole mode of consideration. The second category involves 45 acquiring firms where the mode of consideration is other than purely in cash. ${ }^{13}$ The alternative modes of consideration employed by these latter firms include the issue of shares by the acquiring firm, the issue of convertible bonds by the acquiring firm, warrants issued by the acquiring firm, the transfer of some of the acquiring firm's assets to the shareholders of the target firm, the repayment of some of the target firm's debt by the acquiring firm, or some combination of all of these. Given that we can explicitly identify 168 pure cash transactions and 45 non pure-cash deals, we focus on comparing these two groups when testing if the mode of consideration affects the acquiring firms' abnormal returns.

Our empirical analysis is based around the following questions: i) What are the economic benefits that accrue to Chinese acquirers? (Section 5); ii) What

\footnotetext{
${ }^{11}$ Over this period the Chinese Chaorman, Xiaoping Deng, made a series of political pronouncements for market reforms which was to create a "socialist market economy". In early 2000s a series of new economic policies were established, such as more balanced wealth distribution, improved education, medical care and social security.

12 In a column entitled "All Change", the 10 December, 2011 number of the Economist notes that "China had to relax over 7,000 tariffs, quotas and other trade barriers" in the run up to its admission to the WTO in 2001.

${ }^{13}$ There are 66 firms for which there was insufficient information on the SDC database to identify the mode of consideration used in the takeover. Thus, these 66 firms are excluded from our statistical analysis based on the payment method employed in the acquisition.
} 
are the reasons for any differences in our empirical results when compared to those from the western literature in terms of economic benefits that accrue to acquiring firms? (Section 6); iii) What is the impact of using different payment methods for takeovers on the economic benefits which accrue to Chinese acquirers? (Sections 7 and 8) and, iv) What are the potential reasons of larger economic benefits for non-cash takeovers when compared to pure cash takeovers? (Section 9). Moreover, we use the newly developed Modified Corrado test of Ataullah et al. (2011) to assess the significance of the economic benefits which accrue to Chinese acquirers. However, we also conduct robustness tests on the significance of economic benefits for Chinese acquirers by using the original Corrado (1989) test and the Patell (1976) test throughout the paper.

\section{Methodology}

We retrieve daily closing share price data (adjusted for rights issues and other stock splits) from Datastream for the 279 Chinese acquiring firms comprising our sample as well as the required data relating to the relevant stock market indices. We then compute the continuously compounded daily returns for the A shares of these $N=279$ acquiring firms. The index used to proxy for the market index was the most inclusive index available for the particular stock market. For example, the Shanghai stock Exchange Composite Index was selected as a proxy for the return on the market index for A shares traded on the Shanghai stock Exchange; the Shenzhen stock Exchange Composite Index was used to proxy for the market return for $A$ shares listed on the Shenzhen stock Exchange.

The standard hypothesis tested in the literature is that no economic rents (that is, excess returns) are earned by the shareholders of acquiring firms involved in M\&A activities. Hence our "base-line" methodology involves using the "market model" to determine the expected return on an acquiring firm's A shares around the takeover announcement date. The market model, takes the following form:

$$
R_{i t}=a_{i}+b_{i} R_{m t}+e_{i t}
$$


where $R_{i t}$ is the continuously compounded return on the A shares of the $\mathrm{i}^{\text {th }}$ firm during the $\mathrm{t}^{\text {th }}$ time period (in our case, $\mathrm{t}^{\text {th }}$ day) and $R_{m t}$ is the continuously compounded return on the proxy for the market portfolio during the $t^{\text {th }}$ time period (again, the $\mathrm{t}^{\text {th }}$ day). We estimate $b_{i}$ using OLS and also, the Dimson (1979) procedure that ameliorates for thin-trading effects. Finally, $e_{i t}=A R_{i t}$ is an estimate of the "unexpected" or "abnormal" return on the A shares of the $\mathrm{i}^{\text {th }}$ firm during the $t^{\text {th }}$ time period. All parameters are estimated using returns from 207 trading days preceding the announcement date of the proposed takeover until seven trading days prior to the announcement date; that is, the estimation period was over an interval comprising $(-207,-7)$ trading days. It is important to note that day zero (0) is defined as the first public announcement date of the proposed takeover as listed in the SDC (M\&A) data base. Our event window encompasses six trading days prior to the announcement of the takeover until 17 trading days subsequent to the announcement date; that is, an interval comprising $(-6,+17)$ trading days.

The average abnormal return on the $\mathrm{t}^{\text {th }}$ trading day across the $N=279$ acquiring firms in our sample will be $A A R_{t}=\frac{1}{N} \sum_{i=1}^{N} A R_{i t}$. Similarly, the cumulative abnormal return, $C A R_{i t}$, for the $\mathrm{i}^{\text {th }}$ firm on the $\mathrm{t}^{\text {th }}$ trading day is obtained by summing the abnormal returns, $A R_{i t}$, for the given firm up to and including the $t^{\text {th }}$ trading day of the event window. Since we use an event window comprised of $T=24$ trading days this means that the cumulative abnormal return for the $\mathrm{i}^{\text {th }}$ firm on the $\mathrm{t}^{\text {th }}$ trading day of the event window will be computed as $C A R_{i t}=\sum_{\tau=1}^{t} A R_{i \tau}$. This in turn means that the cumulative average abnormal return on the $\mathrm{t}^{\text {th }}$ day of the event window across the $\mathrm{N}$ firms comprising our sample will be $C A A R_{t}=\frac{1}{N} \sum_{\tau=1}^{t} \sum_{i=1}^{N} A R_{i \tau}=\sum_{\tau=1}^{t} A A R_{\tau}$. Now the central question here is whether the AAR's and/or the CAAR's on any particular date are significantly different from zero in a statistical sense. Three statistics are used to make assessments of this hypothesis; namely the Patell 
(1976) "t" statistic, the Corrado (1989) " $\mathrm{z}$ " statistic and the modified Corrado "z" statistic of Ataullah et al. (2011). Since the modified Corrado statistic had the most consistent record of detecting abnormal performance and yet, is the least known of the three statistics, we now provide a brief summary of the testing procedures on which this statistic is based. ${ }^{14}$

Suppose one estimates the market model and then computes the abnormal returns, $A R_{i t}$, for each of the $i=1,2,3, \ldots, N$ acquiring firms comprising our sample across the $t=1,2,3, \ldots, T$ daily time periods on which our empirical analysis is based. One can then let $1 \leq K\left(A R_{i t}\right) \leq T$ be the rank for the $\mathrm{i}^{\text {th }}$ firm of the abnormal return during the $t^{\text {th }}$ time period. It then follows that one can sum the ranks across the $i=1,2,3, \ldots, N$ firms and thereby determine the significance of the sum of the abnormal returns on a given date $(t)$ using the following non-parametric test statistic:

$$
z_{1}=\sqrt{\frac{3}{N\left(T^{2}-1\right)} \sum_{i=1}^{N}\left[2 K\left(A R_{i t}\right)-(T+1)\right]}
$$

This is the modified Corrado test statistic for the AAR as developed by Ataullah et al. (2011, p. 592). Here it can be shown that $z_{1}$ is asymptotically distributed $(N \rightarrow \infty)$ as a standard normal variate (Fisz, 1963, p. 197).

Moreover, one can also define the accumulated abnormal return for the $i^{\text {th }}$ firm, $C A R_{i t M}$, for $M$ periods beyond the event period, $\mathrm{t}$, as:

$$
C A R_{i t M}=\sum_{j=1}^{M} A R_{i(t+j)}
$$

However, under the modified Corrado test, the concern is not so much with the abnormal return during any particular time period as it is with its rank

\footnotetext{
${ }^{14}$ Here it is important to emphasise that the modified Corrado test does not require the assumption that abnormal returns are normally distributed - unlike the parametric tests (e.g. Patell, 1976 and the standard "t" tests) that are normally applied in empirical work in this area of the literature. Moreover, the modified Corrado test has a much higher relative asymptotic efficiency than other commonly used non-parametric tests of this type (Ataullah et al. 2011).
} 
relative to the other $\mathrm{T}$ abnormal returns for the particular firm and period under investigation. Given this, let:

$$
K\left(C A R_{i t M}\right)=\sum_{j=1}^{M} K\left(A R_{i(t+j)}\right)
$$

be the sum of the ranks of the individual abnormal returns over the $M$ periods beyond the event date $(\mathrm{t})$ for the $\mathrm{i}^{\text {th }}$ of the $\mathrm{N}$ firms on which the empirical analysis is based. It then follows that one can determine the significance of the CAAR over the $M$ periods beyond the event date ( $t$ ) using the following non-parametric test statistic:

$$
z_{3}=\sqrt{\frac{3}{M N(T+1)(T-M)} \sum_{i=1}^{N}\left[2 K\left(C A R_{i t M}\right)-M(T+1)\right]}
$$

This is the modified Corrado test statistic for the significance of the CAAR as developed by Ataullah et al. (2011, p. 597). Here it can be shown that $z_{3}$ is asymptotically distributed $(N \rightarrow \infty)$ as a standard normal variate (Fisz, 1963, p. 197).

We now develop the modified Corrado " $z$ " statistic for comparing returns accruing to cash purchases with those from other modes of consideration. We begin by outlining the test for AARs. Let $z_{i t}^{c}$ be the modified Corrado $z_{1}$ statistic corresponding to the abnormal return for the $i^{\text {th }}$ acquiring firm on the $\mathrm{t}^{\text {th }}$ day of the event window where the takeover consideration is purely in cash. It then follows that $\overline{z_{i t}^{c}}=\frac{1}{N} \sum_{i=1}^{N} z_{i t}^{c}$ will be the average modified Corrado $z_{1}$ statistic for the abnormal returns across the $\mathrm{N}$ firms during the $\mathrm{t}^{\text {th }}$ day of the event window where the takeover consideration is solely in cash. Moreover, $\overline{z_{i t}^{c}} \sqrt{N}$ will be asymptotically distributed $(N \rightarrow \infty)$ as a standard normal variate (Fisz, 1963, p. 197).

Next, let $z_{i t}^{o}$ be the modified Corrado $z_{1}$ statistic corresponding to the 
abnormal return for the $i^{\text {th }}$ acquiring firm on the $\mathrm{t}^{\text {th }}$ day of the event window where the takeover consideration is other than purely in cash. It then follows that $\overline{z_{i t}^{o}}=\frac{1}{M} \sum_{i=1}^{M} z_{i t}^{o}$ will be the average modified Corrado $z_{1}$ statistic across the $M$ firms during the $t^{\text {th }}$ day of the event window where the takeover consideration is other than purely in cash. Furthermore, $\overline{z_{i t}^{o}} \sqrt{M}$ will be asymptotically distributed $(M \rightarrow \infty)$ as a standard normal variate (Fisz, 1963, p. 197).

Now, one can test the hypothesis that the mean modified Corrado $z_{1}$ score for acquiring firms where the consideration is solely in cash is identical to the mean modified Corrado $z_{1}$ score for acquiring firms where the consideration is other than purely in cash by using the test statistic:

$$
\overline{z_{t}^{c o}}=\frac{1}{\sqrt{2}}\left\{\overline{z_{i t}^{c}} \sqrt{N}-\overline{z_{i t}^{o}} \sqrt{M}\right\}
$$

which will be asymptotically $(N, M \rightarrow \infty)$ distributed as a standard normal variate (Fisz, 1963, p. 197). This is equivalent to testing the hypothesis that the AAR on the $t^{\text {th }}$ day of the event window for the acquiring firms where the consideration is purely in cash is the same as the AAR on the $\mathrm{t}^{\text {th }}$ day of the event window for acquiring firms where the consideration is other than purely in cash.

Our testing procedures for the CAARs are analogous to those for the modified Corrado $z_{1}$ statistics associated with the AARs which accrue to the shareholders of Chinese acquiring firms and are based on the test statistic $\overline{z_{t}^{c o}}$ which is defined as follows:

$$
\overline{z_{t}^{c o}}=\frac{1}{\sqrt{2}}\left\{\overline{z_{i t}^{c}} \sqrt{N}-\overline{z_{i t}^{o}} \sqrt{M}\right\}
$$

Here $z_{i t}^{c}$ is the average modified Corrado $z_{3}$ statistic for the cumulative 
abnormal returns across the $i=1,2,3, \ldots, N$ acquiring firms where the mode of consideration is solely in cash, $\overline{Z_{i t}^{o}}$ is the average modified Corrado $Z_{3}$ statistic for the cumulative abnormal returns across the $i=1,2,3, \ldots, M$ acquiring firms where the consideration is other than purely in cash and $t=-6,-5,-4$, _ $, 15,16,17$ is the particular date in the event window. The probability density of the test statistic $\overline{z_{t}^{c o}}$ asymptotically $(N, M \rightarrow \infty)$ converges to that of the standard normal distribution (Fisz, 1963, p. 197). We emphasise again that a test based on the $\overline{z_{i t}^{o}}$ statistic is equivalent to testing the hypothesis that the CAAR on the $\mathrm{t}^{\text {th }}$ day of the event window for acquiring firms where the consideration is solely in cash is the same as the CAAR on the $\mathrm{t}^{\text {th }}$ day of the event window for acquiring firms where the consideration is other than purely in cash.

\section{Analysis of the Economic Benefits of M\&A for Chinese Acquirers}

Table 2 provides a summary of the average abnormal returns (AARs) across the $N=279$ Chinese acquiring firms over the 24 trading days comprising our event window. It is readily observed from this table that the abnormal returns of Chinese acquiring firms are relatively small but statistically significant on the day prior to the takeover announcement date (that is, time -1). For example, the AAR one day before the takeover announcement date is $0.29 \%$ based on Dimson (1979) betas and $0.20 \%$ based on OLS betas ${ }^{15}$. However, both the significance and magnitude of the AARs hinge on the method used to estimate the parameters of the market model (OLS or Dimson) and the testing procedure employed to assess the significance of the AARs (Patell, Corrdao or modified Corrado). Thus, if one uses the Dimson (1979) technique for parameter estimation, then the Corrado (1989) and modified Corrado test statistics for the AARs on the day before the takeover announcement date (that is, time -1 in Table 2) are both statistically significant at the $5 \%$ level. However, when parameter estimation is based on OLS, then both Corrado

\footnotetext{
${ }^{15}$ In order to lower investor burden, China has been continuing to cut transaction costs in trading shares in recent years. The brokerage fee is currently $0.0087 \%$ which applies for both the Shanghai and Shenzhen stock exchanges.
} 
test statistics decline to the point where they are significant at the $10 \%$ level only. Interestingly, the Patell (1976) test statistic is insignificant; and this applies irrespective of whether parameter estimation is based on the OLS or the Dimson (1979) techniques.

The AARs for acquiring firms which are summarised in tabular form in Table 2 are given graphical representation in Figure 1. This graph shows that the AARs for the Chinese acquiring firms comprising our sample are small and positive (though generally insignificant in a statistical sense) in the days leading up to the takeover announcement date. Beyond the takeover announcement date, however, the AARs are generally small and negative culminating with a statistically significant negative abnormal return of just under one half of one per cent on the tenth day after the announcement date. Hence, any significant abnormal returns which accrue to the Chinese acquiring firms comprising our sample decay away in the few trading days subsequent to the takeover announcement date, so much so that the total of the abnormal returns is close to zero by the end of our event window. In summary, our analysis shows that whilst Chinese acquiring firms obtain positive and significant economic benefits around the takeover announcement date, they tend to fall away in the few days subsequent to the announcement date.

Table 3 summarises the CAARs for the Chinese acquiring firms comprising our sample. This table shows in particular that there are significant positive CAARs on the trading day immediately preceding the takeover announcement date (that is, time -1) and on the first and second trading days subsequent to the takeover announcement date (that is, time 1 and time 2, respectively). Thus, for Dimson (1979) betas the Patell (1976) statistic on the first trading day after the takeover announcement date amounts to 2.6900. This is significant at the 1\% level. The Corrado (1989) and modified Corrado statistics are significant at the $5 \%$ level at 2.2496 and 2.4877 , respectively. These positive CAARs begin a process of gradual decay on the third and subsequent trading days following the takeover announcement date. A graphical summary of the CAARs for the Chinese acquiring firms comprising 
our sample is provided in Figure 2. One can clearly see from the this graph that the CAARs based on Dimson (1979) betas reach a statistically significant peak of $1.66 \%$ on the first trading day following the takeover announcement date. ${ }^{16}$ However, the CAARs then gradually decay away from the third trading day subsequent to the takeover announcement date.

In summary, our analysis here confirms what we found in Table 2; which is that there are some significant positive abnormal returns for Chinese acquiring firms around the takeover announcement date. However, these significant and positive abnormal returns quickly decay away in the few days subsequent to the takeover announcement date. In other words, shareholders of Chinese acquiring firms obtain significant positive economic benefits both in terms of AARs and CAARs for only a very short period surrounding the takeover announcement date.

\section{Discussion of reasons why Chinese case differs from Western literature}

One may contrast the above results for China with those appearing in the western literature, which show that western acquiring firms obtain virtually no economic benefits from their M\&A activities. For western firms the abnormal returns tend to be negative over most of the event window although there is mixed evidence on whether these are significantly different from zero (Bruner, 2003; Martynova and Renneboog, 2008). In contrast Chinese acquiring firms tend to earn statistically significant positive abnormal returns around the takeover announcement date. It is important that we identify the underlying reasons for the significant differences which appear to exist between the wealth effects of Chinese and western M\&A activities for acquiring firms. To do this, we link our empirical results to the Chinese political, economic and capital systems, all of which are fundamentally different from those of western countries.

In western countries target firms tend to negotiate the offer price with acquirers so as to maximise the price paid, whereas in the Chinese case there

\footnotetext{
${ }^{16}$ After deduction of brokerage fees which is currently $0.0087 \%$ the magnitude of CAAR is still relatively large.
} 
is less scope for this since some parties are only entitled to the book value (and not the market value) of their shares. Here the Chinese tender offer rules, which form part of the Takeover Measures 2006, provide that a Chinese acquiring firm must submit separate offer prices for the tradable shares and the non-tradable shares of the target firm. The offer price for the tradable shares is determined by reference to the market price on the stock exchange of those shares whilst the offer price for the non-tradable shares is based on the net asset (book) value of the target firm as summarised in its latest set of audited financial statements. Here it is important to emphasise that prior to 2005 non-tradable shares accounted for a majority of the shares on issue by most listed Chinese firms. ${ }^{17}$ Furthermore, regulatory approval needs to be given before the acquisition is publicly announced, which greatly reduces the prospect of a bidding war for the target. Consequently, in the Chinese case due to the environment within which acquisitions take place, the target has less capacity to inflate the offer price relative to western markets and hence it is intuitive that Chinese acquirers receive more economic benefit and higher CAARs than their western counterparts.

\section{Impact of Mode of Consideration on the AARs for Chinese Acquiring Firms}

We have previously noted how there is a substantial western literature which shows that the mode of consideration employed in takeovers can have a

\footnotetext{
${ }^{17}$ As previously noted, in April, 2005 the China Securities Regulatory Commission (CSRC) implemented the Shareholding Structure Reform (Guquan Fenzhi Gaige) under which all nontradable A shares will eventually be converted into tradable A shares. Under the Shareholding Structure Reform, representatives of the group of shareholders with tradable A shares agree terms and conditions for the conversion of non-tradable A shares into tradable $A$ shares with representatives of the group of shareholders who hold the non-tradable $A$ shares. The first firm to successfully convert its non-tradable A shares into tradable A shares under the Shareholding Structure Reform was the Sany Heavy Industry Company. The agreement struck between the tradable and non-tradable shareholders of the Sany Heavy Industry Company specified that non-tradable A shareholders would not be permitted to sell any of their newly created tradable $A$ shares on the stock exchange for the first two years after conversion. Moreover, no more than $10 \%$ of their newly created tradable A shares could be sold on the stock exchange in the third year after conversion. Thus the Sany Heavy Industry Company agreement, which is typical of the agreements which are being reached under the Shareholding Structure Reform, will mean that it was not until 2008 that any of the former non-tradable A shares actually became tradable - and even then, only a very small proportion of them. This in turn means that the distinction between tradable and non-tradable shares remained in place for our entire sample period which, it will be recalled, is based on data covering the period from 1990 to 2008.
} 
significant impact on the economic benefits which accrue to the shareholders of acquiring firms (Martynova and Renneboog, 2008). In this section we present empirical evidence on this matter in relation to Chinese acquiring firms. We commence our analysis by dividing the $N=279$ Chinese acquiring firms comprising our sample into two categories. The first category is comprised of 168 Chinese acquiring firms where cash is the sole mode of consideration. The second category involves 45 acquiring firms where the mode of consideration is other than purely in cash. ${ }^{18}$ The alternative modes of consideration employed by these latter firms include the issue of shares by the acquiring firm, the issue of convertible bonds by the acquiring firm, warrants issued by the acquiring firm, the transfer of some of the acquiring firm's assets to the shareholders of the target firm, the repayment of some of the target firm's debt by the acquiring firm, or some combination of all of these.

A summary of the AARs over the event window using Dimson (1979) estimates of beta and their associated Patell (1976) "t" statistics, Corrado (1989) " $z$ " statistics and the modified Corrado " $z$ " statistics for cash as against alternative modes of consideration is provided in Table $4 .^{19} \mathrm{~A}$ graphical summary of the AARs is given in Figure 3. The second column of Table 4 summarises the AARs across the 168 Chinese acquiring firms where the mode of consideration is solely in cash. The third column summarises the AARs across the 45 acquiring firms where alternative modes of consideration are employed. For both pure cash and alternative modes of consideration the AARs tend to be positive in the six trading days prior to the takeover announcement date. On the takeover announcement date itself (time zero), there is a strong positive AAR of $0.92 \%$ for takeovers financed through alternative modes of consideration. This compares with a modest AAR of $0.06 \%$ on the same date for takeovers financed purely through cash. After the

\footnotetext{
${ }^{18}$ We have previously noted that there are 66 firms for which there was insufficient information on the SDC database to identify the payment method used in the takeover. We thus exclude these 66 firms from our empirical analysis.

19 Our results do not vary according to whether they are based on Dimson (1979) estimates of beta or OLS estimates of beta. Thus, for brevity we report results based on the Dimson (1979) estimate of beta only.
} 
takeover announcement date there are as many positive as there are negative AARs for both cash and alternative modes of consideration, although the positive AARs tend to be larger in absolute terms for takeovers financed through alternative modes of consideration. This reinforces our finding that the AARs for shareholders of Chinese acquiring firms with alternative modes of consideration tend to exceed the AARs for takeovers that are financed purely through cash.

The fourth, seventh and tenth columns of Table 4 summarise the Patell (1976) " $t$ " statistics, the Corrado (1989) " $\mathrm{z}$ " statistics and the modified Corrado " $\mathrm{z}$ " statistics associated with the AARs of the 168 acquiring firms where cash is the sole mode of consideration. Here we have previously noted that the AARs over the period leading up to the takeover announcement date are all positive. However, none of the Patell (1976) " $\mathrm{t}$ " statistics associated with the AARs for this period turn out to be statistically significant at generally accepted levels. In contrast, both the Corrado (1989) and the modified Corrado " $\mathrm{Z}$ " statistics are statistically significant at the $1 \%$ level on the takeover announcement date itself (with statistics of 2.7599 and 2.5423, respectively). There is also a preponderance of negative AARs after the takeover announcement date. The modified Corrado test provides evidence of this at the $5 \%$ level for both days 9 and 10 of the event window, while the original Corrado (1989) test and the Patell (1976) test are significant at the 5\% level on one of these days and at the $10 \%$ level on the other day.

The fifth, eighth and eleventh columns of Table 4 summarise the Patell (1976) " $t$ " statistics, the Corrado (1989) " $\mathrm{z}$ " statistics and the modified Corrado " $\mathrm{z}$ " statistics associated with the AARs of the 45 acquiring firms where alternative modes of consideration are employed. Note that prior to the takeover announcement date the AARs for alternative modes of consideration are generally insignificantly different from zero. On the takeover announcement date itself, when the AAR peaks at almost 1\%, all three test statistics are statistically significant at the $10 \%$ level. The modified Corrado test also identifies positive and statistically significant AARs on the second, sixth and eleventh trading days after the takeover announcement date as well as 
statistically significant negative AARs on the ninth and thirteenth trading days after the takeover announcement date. This contrasts with the Patell (1976) and Corrado (1989) tests which identify only two and three, respectively of these latter five AARs as being significantly different from zero.

The sixth, ninth and twelfth columns of Table 4 summarise the $z$ statistics for differences in the AARs between pure-cash and non-pure cash transactions. For all three tests, none of the $z$ statistics are significant prior to the takeover announcement date. However, the modified Corrado $\overline{z_{t}^{c o}}$ statistics are negative and significantly different from zero on the second, third and tenth trading days subsequent to the takeover announcement date. The Corrado (1989) statistics are also significantly negative on the second and third trading days subsequent to the takeover announcement date. These results imply that shareholders of acquiring firms where alternative modes of consideration are employed obtain significantly larger AARs than shareholders of acquiring firms where the consideration is solely in cash only over a very narrow event window immediately after the takeover announcement date. At other times in the event window there is very little evidence of significant differences in the wealth effects between pure cash takeovers and takeovers financed using alternative modes of consideration.

We may summarise our analysis of Table 4 by noting that for takeovers financed purely through cash the Corrado (1989) and Modified Corrado "z" tests detect positive and significant economic benefits only on the takeover announcement date itself. Subsequent to this date, however, all three tests show that there are occasional significant economic losses. In contrast, there are significant positive economic benefits both on and after the takeover announcement date for the shareholders of Chinese acquiring firms where alternative modes of consideration are employed. Further, our analysis based on differences between the AARs for pure cash takeovers as against the AARs for alternative modes of consideration show that returns to alternative modes of consideration are only statistically larger for a few trading days immediately following the takeover announcement date itself. 


\section{Impact of Mode of Consideration on the CAARs for Chinese Acquiring Firms}

We now examine the impact that the mode of consideration has on the CAARs that accrue to shareholders of Chinese acquiring firms. Here Table 5 summarises the CAARs based on Dimson (1979) betas ${ }^{20}$ and their associated Patell (1976) "t", Corrado (1989) "z" and modified Corrado (Ataullah et al., 2011) " $z$ " scores for the 168 Chinese acquiring firms involved in pure-cash deals and the 45 deals where alternative modes of consideration were used.

The second column of Table 5 shows that the CAARs for shareholders of acquiring firms where cash is the sole mode of consideration gradually increase in the run up to the takeover announcement date. In particular, the CAAR peaks on the first trading day after the takeover announcement date at $1.44 \%$. Beyond this date, however, the CAARs decay away quite sharply so much so that by the tenth trading day after the takeover announcement date the CAAR reaches a minimum over the entire event window of $-0.16 \%$. In contrast, the third column of Table 5 shows that the CAARs for alternative modes of consideration gradually increase in magnitude until seven trading days after the takeover announcement date where they reach a peak of $3.38 \%$. The CAARs tend to decline after this date and then stabilise towards the end of the event period at about $1.60 \%$. The CAARs for the pure cash and alternative modes of consideration are graphed in Figure 4 for Dimson (1979) betas. A key finding, immediately apparent from Figure 4 and Table 5 is that the overall CAARs of Chinese acquirers where alternative modes of consideration are employed are significantly larger than the CAARs where only cash is used.

The fourth, seventh and tenth columns of Table 5 summarise the test scores associated with the Patell (1976), Corrado (1989) and modified Corrado statistics for CAARs of Chinese acquiring firms where the consideration is solely in cash. Note how the test scores associated with the CAARs for all three statistics are not significantly different from zero except on the takeover

${ }^{20}$ Our results do not vary according to whether they are based on Dimson (1979) estimates of beta or OLS estimates of beta. Thus, for brevity we only report results based on the Dimson (1979) estimate of beta. 
announcement date itself $(\mathrm{t}=0)$ and the first trading day after the takeover announcement date $(t=1)$. All three tests find that the CAAR is significantly different from zero on the first trading day after the takeover announcement date at the $10 \%$ level or better and the Corrado (1989) test also finds that the CAAR is significant at the $5 \%$ level on the takeover announcement date itself. However, this significance disappears as the event window progresses. Overall, we conclude that there is minimal statistical evidence of economic benefits for the shareholders of Chinese acquiring firms when the mode of consideration is purely in cash.

The fifth, eighth and eleventh columns of Table 5 summarise the test scores associated with the Patell (1976), Corrado (1989) and modified Corrado statistics for CAARs of Chinese acquiring firms where alternative modes of consideration are used. Here, the Patell (1976) test results indicate that almost all of the CAARs over the event window are insignificantly different from zero. This is in marked contrast with the test scores for the Corrado (1989) and modified Corrado " $z$ " statistics which are significant at the $10 \%$ level or better on the second through until at least the eighth trading day after the takeover announcement date. These results are consistent with the hypothesis that there are significant economic benefits for the shareholders of Chinese acquiring firms when alternative modes of consideration are employed.

Our analysis up to this point suggests that the CAARs which accrue to the shareholders of Chinese acquiring firms where alternative modes of consideration are employed tend to be larger than the CAARs for pure cash deals. We now report the results of a formal test of this hypothesis. Here, the sixth, ninth and twelfth columns of Table 5 summarise the $z$ statistics associated with the differences between the CAARs for pure cash as against alternative modes of consideration for the Patell (1976), Corrado (1989) and modified Corrado test statistics. Interestingly, for the Patell (1976) test and the original Corrado (1989) test none of the $z$ scores are statistically different from zero at any point during the entire event window. However, the $\overline{z_{t}^{c o}}$ statistics associated with the modified Corrado test as summarised in the 
twelfth column of Table 5 shows that from the fifth trading day after the takeover announcement date until the end of the event window the vast majority of $\overline{z_{t}^{c o}}$ statistics are negative and significantly different from zero. This result is compatible with the hypothesis that the CAARs accruing to the shareholders of Chinese acquiring firms where alternative modes of consideration are employed exceed the CAARs for the shareholders of acquiring firms where cash is the sole mode of consideration. This is a particularly interesting result in light of the fact that Ataullah et al. (2011) have shown that the modified Corrado test is likely to have significantly more power than either the Patell (1976) or original Corrado (1989) test when stock returns do not evolve in terms of the normal distribution.

In summary, the analysis reported in Table 5 shows that when cash is used as the sole mode of consideration, there are no significant economic benefits for shareholders of Chinese acquiring firms apart from a very narrow window surrounding the takeover announcement date. However when alternative modes of consideration are employed there are significant economic benefits for the shareholders of acquiring firms over the vast majority of the event window subsequent to the takeover announcement date. Moreover, the CAARs which accrue to the shareholders of Chinese acquiring firms where alternative modes of consideration are used are larger than the CAARs for shareholders of acquiring firms where cash is used as the sole mode of consideration. This is in marked contrast to results summarised in the western literature (Martynova and Renneboog, 2008).

\section{Potential Reasons Contributing to the Larger Economic Benefits for non-cash deals than pure cash takeovers}

Our empirical analysis shows that when cash is used as the sole mode of consideration in Chinese M\&A activities shareholders of Chinese acquiring firms obtain no significant economic benefits either in terms of the AARs or CAARs that arise in a 24-day event window surrounding the takeover announcement date. However, when alternative modes of consideration are employed the shareholders of Chinese acquiring firms achieve significant economic benefits from takeovers in terms of both the AARs and the CAARs 
which arise over the event window. We now provide a brief summary of the possible reasons as to why the CAARs for Chinese acquiring firms that use alternative modes of consideration are larger than the CAARs for acquiring firms where cash is the sole mode of consideration.

Huang and Walking (1987) note that when cash is employed as the sole mode of consideration, target firms will tend to demand higher takeover premiums due to the capital gains tax which will have to be paid by the shareholders of the target firm immediately after the takeover is consummated. However, if alternative modes of consideration are employed (shares, in particular) then the capital gains $\operatorname{tax}^{21}$ can be deferred until such times as the shares issued by the acquiring firm to finance the takeover are sold. Thus, the lower costs associated with using alternative modes of consideration should mean that there will be greater economic benefits for the shareholders of the acquiring firm. This hypothesis is consistent with our empirical results which show that the economic benefits for shareholders of acquiring firms are larger when alternative modes of consideration are used to finance M\&A activities. Our evidence is particularly interesting given that the majority of prior US and developed market evidence does not support this tax hypothesis, since cash deals earn higher CAARs than non-cash deals in developed markets (Martynova and Renneboog, 2008).

A second reason is that acquiring firms will prefer to use alternative modes of consideration because of the information asymmetries that arise in the takeover process (Hansen, 1987). In particular, target firms will tend to have a much better understanding of the value their own physical assets, their productive activities and their prospective contractual arrangements. Moreover, acquiring firms will have private information about the intrinsic value of their own shares. Hansen (1987) argues that these information asymmetries may lead acquiring firms to offer stock rather than cash for the proposed takeover, especially when the acquiring firm knows that its shares are over-valued on the stock market. The difference between the stock market value of the acquiring firm's shares and their intrinsic value will lower

\footnotetext{
${ }^{21}$ The capital gain tax stands at $20 \%$ in China.
} 
the implicit cost of the takeover and thereby increase the economic benefits that accrue to the shareholders of the acquiring firm. Financing the takeover through the acquiring firm's stock rather than cash also transfers some of the risks associated with the takeover from the acquiring firm's shareholders to the target firm's shareholders.

We now conduct additional empirical analysis to test the predictions of Hansen (1987). First, we examine if the choice of mode of consideration is related to the relative value of the acquiring firm's stock and secondly, we examine whether the difference in CAARs for alternative modes of consideration versus cash offers is driven by the relatively high valued firms comprising our sample. In our analysis we examine the log market-adjusted earnings-price ratio as our valuation measure. ${ }^{22}$ The lower the log marketadjusted earnings-price (EP) ratio the more highly valued the company is. We use two dummy variables as indicators of overvaluation in both tests related to EP. Over_Val_Med is 1 if the market-adjusted earnings-price ratio is below the median and Over_Val_33 is 1 if the market-adjusted earnings-price ratio is below the $33^{\text {rd }}$ percentile. We also include four measures based on marketadjusted book-market ratio (BM); these provide additional robustness by using an alternative valuation proxy and versions are estimated where the market adjustment is done on the basis of the equally-weighted ratio (WC1) and the median (WC2). For examining if the mode of consideration is affected by valuation we also use the log market-adjusted earnings-price ratio itself; that is, log EP difference and the rank of the log market-adjusted earnings-price ratio (log EP difference rank).

Table 6 reports results from logit regressions of a dummy variable for the mode of consideration ( 1 if alternative consideration; 0 if pure cash) on measures of valuation. These demonstrate strong support for the Hansen

\footnotetext{
${ }^{22}$ That is the natural logarithm of the firm's earnings-price ratio plus 0.001 minus the natural logarithm of the market earnings-price ratio plus 0.001 [In $\left.\left(0.001+E P_{i}\right)-\ln \left(0.001+E P_{M}\right)\right]$. Here we follow Boudoukh et al. (2007, p. 893) in adding 0.001 to all earnings-price ratios in order to insure that the argument of the logarithmic function is strictly positive. Using a log transformation means that our results are not sensitive to whether earnings-price ratio or price-earnings ratio is used. However, we also based our logit regressions on several other transformations - for example, the inverse sinh which is often used to mitigate problems of heteroscedasticity (Anscombe, 1948; Laubscher, 1961; Sokal and Rohlf, 1981) - with little difference to the results summarised in Table 6.
} 
(1987) prediction that more over-valued acquirers are more likely to use alternative modes of consideration. For example, the coefficient on log EP difference rank is 0.007 , which is statistically significant at all conventional levels. The positive coefficient indicates that an increase in rank leads to a higher likelihood that an alternative mode of consideration will be used. This positive significant effect is corroborated by all the valuation dummy variables both those based on EP and on BM. In appendix B. 6 we included some control variables for the mode of consideration, which are linked to the size of retained earnings (cash reserves to market ratio and operating margin (operating income / sales)) or the ease of accessing external market financing (log of market capitalisation). The main results for over-valuation proxies are generally strengthened compared to Table 6 . We can report that none of the control variables were statistically significant in any regression at the $5 \%$ level and only log market capitalisation was ever significant at the $10 \%$ level.

Table 7 reports results from Mann-Whitney tests of equal ranks. We examine the ranks of the CAARs grouped by the mode of consideration. We report results for 2 windows, the immediate period around the earnings announcement ( $\mathrm{t}-1$ to $\mathrm{t}+2)$, and the full sample period ( $\mathrm{t}-6$ to $\mathrm{t}+17)$. The results from panel $A$ indicate for the full sample that the cash deals have lower CAAR ranks than the alternative deals for both CAAR windows; this is consistent with our previous analysis in section 8. When we run sub-sample analysis, in panel $B$, only for those acquiring firms which are over-valued, then we also find that cash deals have lower CAAR ranks than the alternative deals. This result is relatively insensitive to the overvaluation dummy used or to the CAAR window selected; all the $p$-values in panel $B$ are less than 0.06 . In contrast, in panel $C$, when we run sub-sample analysis only for those firms that are not highly valued, we find that the CAAR ranks are similar regardless of the mode of consideration; that is, CAAR is unrelated to mode of consideration when firms are not highly valued. These results strongly support Hansen's (1987) assertion that the economic benefits for over-valued acquiring firms from alternative modes of consideration will be larger than those from pure cash deals. 
Our empirical results also have some important implications for practice. They show in particular that financing M\&A activities through alternative modes of consideration brings significant economic benefits to the shareholders of Chinese acquiring firms. In contrast, when cash is used as the sole mode of consideration there are few if any economic benefits for the shareholders of acquiring firms. Hence, if Chinese acquiring firms are to maximise the economic benefits that accrue to their shareholders they should normally finance their $M \& A$ activities using alternative modes of consideration. Given this, it is somewhat perplexing that the vast majority of Chinese takeovers continue to be financed solely in cash, even after the implementation of the shareholding structure reforms of 2005 (Guquan Fenzhi Gaige) which both facilitated and encouraged the use of alternative modes of consideration in Chinese M\&A activities.

\section{Summary and Conclusions}

This paper provides the first detailed empirical analysis of the economic benefits which accrue to shareholders of Chinese acquiring firms as a result of their M\&A activities. Our empirical evidence on the returns earned by Chinese acquiring firms provides three main findings: i) Chinese acquirers overall have positive abnormal returns. This contrasts with the vast majority of prior western literature which shows that there are on average losses (albeit not necessarily statistically significant) for acquiring firms in developed countries. ii) Takeovers involving alternative modes of consideration have higher abnormal returns than cash deals, again in clear contrast to the vast majority of prior literature for developed countries. iii) The difference in CAARs between alternative modes of consideration and cash is driven by firms that are highly valued; this result is consistent with the theoretical model of Hansen (1987).

We especially investigate the effect of using cash as against alternative modes of consideration (e.g. shares of the acquiring firm, warrants on shares of the acquiring firm, debt repayment, etc. and mixtures thereof) in M\&A activities. Our analysis shows that both the AARs and CAARs that accrue to the shareholders of Chinese acquiring firms when alternative modes of 
consideration are used are positive and significantly different from zero in a statistical sense. In contrast, the economic benefits for shareholders of Chinese acquiring firms when cash is used as the sole mode of consideration tend to be insignificantly different from zero and often, negative. Formal tests of the hypothesis that the abnormal returns for Chinese acquiring firms which use alternative modes of consideration are greater than the abnormal returns for acquiring firms which only use cash show that the modified Corrado test provides consistent evidence of statistical differences between the abnormal returns for the two modes of consideration. This contrasts with the Patell (1976) and Corrado (1989) tests which often detect little difference between the abnormal returns for the two modes of consideration. Thus, our empirical analysis confirms that the modified Corrado test is generally more powerful than any of the traditionally used tests in the area (Ataullah et al., 2011).

Our empirical analysis also shows that takeovers financed through alternative modes of consideration generate significantly higher abnormal returns than takeovers financed purely through cash. Again this contrasts with the vast majority of existing literature for developed countries. We outlined two main potential reasons as to why this is the case. First, in China a capital gains tax of $20 \%$ must be paid immediately by the target firm's shareholders when cash is used to finance the takeover. In contrast, when alternative modes of consideration are used, it is normally possible to defer the payment of the capital gains tax. Second, the information asymmetries that arise in the takeover process may lead acquiring firms to offer stock rather than cash for the proposed takeover, especially when the acquiring firm knows that its shares are over-valued on the stock market (Hansen, 1987). The difference between the stock market value of the acquiring firm's shares and their intrinsic value will lower the implicit cost of the takeover and thereby increase the economic benefits that accrue to the shareholders of the acquiring firm. We provide empirical evidence to support both these points: i) the mode of consideration only affects CAARs earned by acquiring firms which are highly valued and ii) highly valued companies are more likely to use alternative modes of consideration than cash. These considerations, when taken in conjunction with our empirical analysis, show that highly valued Chinese 
acquiring firms ought to employ alternative modes of consideration if they are to maximise the economic benefits that accrue to their shareholders from M\&A activities. Given this, it is somewhat perplexing that a large majority of Chinese M\&A activities, even for highly valued firms, continue to be financed solely through cash. 


\section{References}

Amihud, Y., Lev, B., and Travlos, N., 1990. Corporate control and the choice of investment financing: The case of corporate acquisition. Journal of Finance. 45, 603-616.

Anscombe, F., 1948. The transformation of poisson, binomial and negativebinomial data. Biometrika. 35, 246-254.

Asquith, P., 1983. Merger bids, uncertainty, and stockholder returns. Journal of Financial Economics. 11, 51-83.

Asquith, P., Bruner, R. and Mullins, D., 1990. Merger returns and the form of financing. Unpublished working paper, Massachusetts Institute of Technology and University of Virginia.

Ataullah A., Song, X. and Tippett, M., 2011. A modified corrado test for assessing abnormal security returns, European Journal of Finance. 17, 589601.

Boudoukh, J., Michaely, R., Richardson, M. and Roberts, M., 2007. On the importance of measuring payout yield: implications for empirical asset pricing, Journal of Finance. 62, 877-915.

Brown, D. and Ryngaert 1991. The mode of acquisition in takeovers: taxes and asymmetric information. Journal of Finance, 46, 653-669.

Bruner, R.F., 2003. Does M\&A pay? A survey of evidence for the decisionmaker. Journal of Applied Finance. 12, 48-69.

Chen. X. and Zhang T., 1999. The market reaction to the mergers and acquisitions-empirical analysis of $m \& a$ transactions occurred on Shanghai Stock Exchange in 1997. Research on Economy. 9.

Corrado, C., 1989. A nonparametric test for abnormal security price performance in event studies. Journal of Financial Economics. 23, 385-95. 
Dimson, E., 1979. Risk measurement when shares are subject to infrequent trading. Journal of Financial Economics. 17, 197-226.

Dodd, P. and Ruback, R., 1977. Tender offers and stockholder returns: an empirical analysis. Journal of Financial Economics. 5, 351-374.

Fisz, M., 1963. Probability Theory and Mathematical Statistics. Wiley, New York.

Freund, J., 1971. Mathematical Statistics. Prentice-Hall, New Jersey.

Ge, P. and Ping, J., 2009. The empirical research on the mode of consideration after the shareholding structure reform in china. Friends of Accounting. 23.

Hansen, H., 1987. A theory for the choice of exchange medium in mergers and acquisitions. Journal of Business. 60, 75-95

Huang, Y. and Walking, R., 1987. Target abnormal returns associated with acquisition announcements: payment, acquisition form and management resistance. Journal of Financial Economics. 19, 329-349.

Langtieg, T., 1978. An application of a three-factor performance index to measure stockholders gains from merger. Journal of Financial Economics. 6, 365-384.

Laubscher, N., (1961). On stabilizing the binomial and negative binomial variances. Journal of the American Statistical Association. 56, 143-150.

Li, S. and Chen, Y., 2002. The Wealth Effect of Mergers and Acquisitions on the Listed Companies. Research on Economy, 11.

Ma, D., 2014. "Momentum, Acceleration and Non-Linearities in Equity Valuation on the Shanghai Stock Exchange", Unpublished Ph.D dissertion, School of Accounting and Commercial Law, Victoria University of Wellington, New Zealand. 
Martynova, M. and Renneboog, L., 2008. A century of corporate takeovers: what have we learned and where do we stand? Journal of Banking and Finance. 32, 2148-2177.

Patell, J., 1976. Corporate forecasts of earnings per share and stock price behavior: empirical test. Journal of Accounting Research. 14, 246-76.

Qi, D., Wu, W. and Zhang, H., 2000. Shareholding Structure and Corporate Performance of Partially Privatized Firms: Evidence from Listed Chinese Companies. Pacific-Basic Finance Journal, 8(5), pp. 587-610.

Servaes, H. 1991. Tobin's Q and the gains from takeovers, Journal of Finance. 46, 409-419.

Sokal, R. and Rohlf, J., 1981. Biometry: The Principles and Practice of Statistics in Biological Research. Freeman, San Francisco:

Song, X.and Tippett, M., 2013. "The law and regulation of chinese mergers and acquisitions: the takevover measures" in Mohsen Bahmani-Oskooee and Sahar Bahmanu (Eds.), Financial Markets: Recent Developments, Emerging Practices and Future Prospects. Nova Science Publishers, Hauppauge, NY, pp. 153-171.

Savage, R., 1961. Probability inequalities of the tchebycheff type. Journal of Research of the National Bureau of Standards - B. Mathematics and Mathematical Physics. 65B, 211-226.

$\mathrm{Wu}, \mathrm{X}$. and Zhang, M., 2009. The research on the loss of acquiring firms in chinese m\&a activities. Working Paper Series of China Center for Economic Research.

Yook, K., 2003. Larger returns to cash acquisitions: signaling effect or leverage effect? Journal of Business. 76, 477-498.

Yu, G. and Yang, R., 2000. The theoretical and empirical analysis on the impact of mergers and acquisitions. Concurrent Finance and Economy. 7. 
Zhang, Y., Wang, Y. and Meng, L., 2007. The research on the mode of consideration in Chinese merger and acquisitions. Sci-Technology and Management. 


\section{Table 1: Industrial classifications and Dates of Takeovers for $\mathrm{N}=\mathbf{2 7 9}$ Chinese Acquiring firms}

Industry

Automobiles \& Parts

Beverages

Chemicals

Construction \& Materials

Electronic \& Electrical Equipment

Electricity

Financial Services

Food Producers

Forestry \& Paper

General Industrials

General Retailers

Gas, Water \& Multiutilities

Household Goods \& Home Construct

Industrial Engineering

Industrial Metals \& Mining

Industrial Transportation

Leisure Goods

Media

Mining

Oil \& Gas Producers

Personal Goods

Pharmaceuticals \& Biotechnology

Real Estate Investment \& Services

Software \& Computer services

Support Services

Technology, Hardware \& Equipment

Travel \& Leisure

Totals

1995

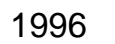

\section{7}

1999

2000 (2001

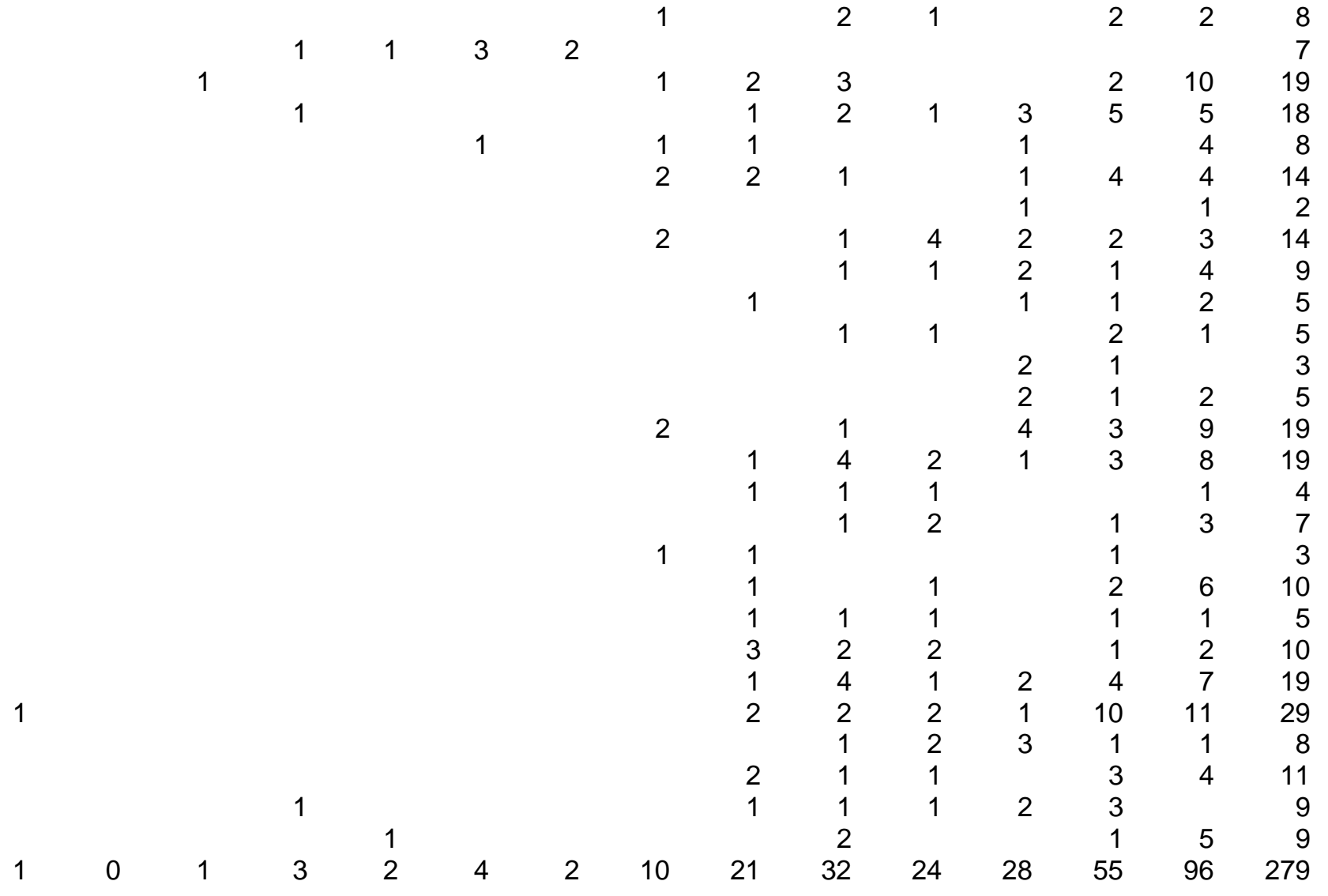


Table 2: Average Abnormal Returns Across N = 279 Chinese Acquiring Firms Covering the Period from January, 1990 until December, 2008

\begin{tabular}{|c|c|c|c|c|c|c|c|c|}
\hline \multirow[b]{2}{*}{ Time } & \multicolumn{3}{|c|}{ Dimson Betas } & \multirow[b]{2}{*}{$\begin{array}{l}\text { Modified } \\
\text { Corrado } \\
\text { Statistic }\end{array}$} & \multicolumn{4}{|c|}{ OLS Betas } \\
\hline & AARs & $\begin{array}{l}\text { Patell } \\
\text { Statistic }\end{array}$ & $\begin{array}{l}\text { Corrado } \\
\text { Statistic }\end{array}$ & & AARs & $\begin{array}{c}\text { Patell } \\
\text { Statistic }\end{array}$ & $\begin{array}{l}\text { Corrado } \\
\text { Statistic }\end{array}$ & $\begin{array}{l}\text { Modified } \\
\text { Corrado } \\
\text { Statistic }\end{array}$ \\
\hline-6 & -0.0001 & 0.21 & -0.29 & 0.00 & -0.0015 & -0.13 & -0.51 & -0.37 \\
\hline-5 & 0.0016 & 0.15 & -0.57 & -0.58 & 0.0031 & 1.02 & -0.48 & -0.50 \\
\hline-4 & 0.0033 & $1.70^{*}$ & 0.62 & 0.65 & 0.0031 & 1.61 & 0.60 & 0.64 \\
\hline-3 & 0.0027 & 1.04 & 0.94 & 0.98 & 0.0028 & 1.01 & 1.05 & 1.11 \\
\hline-2 & 0.0029 & 1.22 & 0.83 & 0.87 & 0.0041 & $1.71^{\star}$ & 1.27 & 1.34 \\
\hline-1 & 0.0029 & 1.09 & $2.32^{\#}$ & $2.42^{\#}$ & 0.0020 & 0.74 & $1.76^{\star}$ & $1.85^{\star}$ \\
\hline 0 & 0.0006 & 0.61 & 1.32 & 1.14 & 0.0014 & 0.85 & $1.87^{\star}$ & 1.63 \\
\hline 1 & 0.0026 & 0.97 & 1.19 & 1.24 & 0.0027 & 0.70 & 1.31 & 1.38 \\
\hline 2 & -0.0042 & -1.62 & -1.60 & $-1.67^{*}$ & -0.0036 & -1.42 & -1.36 & -1.42 \\
\hline 3 & -0.0002 & -1.46 & -1.47 & -1.50 & 0.0006 & -1.19 & -1.15 & -1.21 \\
\hline 4 & -0.0022 & $-1.97^{\#}$ & $-2.03^{\#}$ & $-2.11^{\#}$ & -0.0013 & $-1.80^{*}$ & $-1.75^{\star}$ & $-1.83^{*}$ \\
\hline 5 & -0.0040 & -0.68 & -0.41 & -0.42 & -0.0043 & -0.55 & -0.65 & -0.68 \\
\hline 6 & 0.0038 & 0.87 & $1.80^{*}$ & $1.88^{*}$ & 0.0038 & 0.67 & $1.81^{*}$ & $1.90^{\star}$ \\
\hline 7 & -0.0045 & -1.51 & $-1.84^{*}$ & $-1.92^{*}$ & -0.0039 & -1.36 & $-1.73^{*}$ & $-1.81^{*}$ \\
\hline 8 & 0.0015 & 0.42 & -0.35 & -0.37 & 0.0017 & 0.57 & -0.31 & -0.32 \\
\hline 9 & -0.0018 & -1.41 & -0.63 & -0.66 & -0.0022 & -1.51 & -0.43 & -0.45 \\
\hline 10 & -0.0046 & $-2.03^{\#}$ & $-2.27^{\#}$ & $-2.36^{\#}$ & -0.0044 & $-1.81^{*}$ & $-2.51^{\#}$ & $-2.63^{\$}$ \\
\hline 11 & 0.0011 & 1.56 & 1.27 & 1.33 & 0.0002 & 0.83 & 1.18 & 1.25 \\
\hline 12 & -0.0009 & 0.35 & -0.94 & -0.97 & -0.0011 & 0.50 & -0.79 & -0.83 \\
\hline 13 & -0.0019 & -0.85 & -1.63 & $-1.70^{*}$ & -0.0018 & -0.80 & -1.63 & $-1.71^{\star}$ \\
\hline 14 & 0.0010 & 0.23 & -0.66 & -0.67 & 0.0021 & 0.51 & -0.67 & -0.70 \\
\hline 15 & 0.0015 & 0.96 & 0.03 & 0.03 & 0.0003 & 0.54 & 0.18 & 0.19 \\
\hline 16 & 0.0005 & 0.57 & 0.58 & 0.61 & 0.0002 & 0.45 & -0.03 & -0.02 \\
\hline 17 & 0.0021 & 0.90 & 0.35 & 0.28 & 0.0010 & 0.77 & -0.09 & 0.01 \\
\hline
\end{tabular}


Table 3: Cumulative Average Abnormal Returns Across N = 279 Chinese Acquiring Firms Covering the Period January, 1990 until December, 2008

\begin{tabular}{|c|c|c|c|c|c|c|c|c|}
\hline \multirow[b]{2}{*}{ Time } & \multicolumn{3}{|c|}{ Dimson Betas } & \multirow[b]{2}{*}{$\begin{array}{l}\text { Modified } \\
\text { Corrado } \\
\text { Statistic }\end{array}$} & \multicolumn{4}{|c|}{ OLS Betas } \\
\hline & CAARs & $\begin{array}{c}\text { Patell } \\
\text { Statistic }\end{array}$ & $\begin{array}{l}\text { Corrado } \\
\text { Statistic }\end{array}$ & & CAARs & $\begin{array}{c}\text { Patell } \\
\text { Statistic }\end{array}$ & $\begin{array}{l}\text { Corrado } \\
\text { Statistic }\end{array}$ & $\begin{array}{l}\text { Modifie } \\
\text { Corrad } \\
\text { Statisti }\end{array}$ \\
\hline-6 & -0.0001 & 0.21 & -0.29 & 0.00 & -0.0015 & -0.03 & -0.51 & -0.42 \\
\hline-5 & 0.0015 & 0.18 & -0.61 & -0.48 & 0.0017 & 0.85 & -0.70 & -0.77 \\
\hline-4 & 0.0049 & 1.07 & -0.14 & 0.00 & 0.0048 & 1.53 & -0.23 & -0.29 \\
\hline-3 & 0.0075 & 1.52 & 0.35 & 0.58 & 0.0075 & $1.94^{*}$ & 0.33 & 0.52 \\
\hline-2 & 0.0104 & $1.86^{*}$ & 0.69 & 0.89 & 0.0116 & $2.50^{\#}$ & 0.86 & 1.03 \\
\hline-1 & 0.0134 & $2.26^{\#}$ & 1.57 & $1.84^{*}$ & 0.0136 & $2.62^{\$}$ & 1.50 & $1.67^{\star}$ \\
\hline 0 & 0.0140 & 1.45 & $1.96^{\#}$ & 1.21 & 0.0149 & $1.95^{*}$ & $2.10^{\#}$ & 1.40 \\
\hline 1 & 0.0166 & $2.69^{\$}$ & $2.25^{\#}$ & $2.49^{\#}$ & 0.0176 & $2.98^{\$}$ & $2.43^{\#}$ & $2.51^{\#}$ \\
\hline 2 & 0.0124 & $1.65^{\star}$ & 1.59 & $1.76^{\star}$ & 0.0140 & $1.99^{\#}$ & $1.84^{*}$ & $1.88^{\star}$ \\
\hline 3 & 0.0122 & 1.08 & 1.04 & 1.16 & 0.0146 & 1.45 & 1.38 & 1.19 \\
\hline 4 & 0.0101 & 0.44 & 0.38 & 0.43 & 0.0133 & 0.80 & 0.78 & 0.60 \\
\hline 5 & 0.0061 & 0.24 & 0.25 & 0.28 & 0.0090 & 0.60 & 0.56 & 0.51 \\
\hline 6 & 0.0099 & 0.43 & 0.73 & 0.81 & 0.0128 & 0.73 & 1.04 & 0.90 \\
\hline 7 & 0.0054 & 0.08 & 0.22 & 0.24 & 0.0088 & 0.36 & 0.54 & 0.42 \\
\hline 8 & 0.0069 & 0.17 & 0.12 & 0.13 & 0.0105 & 0.47 & 0.45 & 0.27 \\
\hline 9 & 0.0052 & -0.12 & -0.04 & -0.05 & 0.0083 & 0.13 & 0.32 & 0.17 \\
\hline 10 & 0.0006 & -0.46 & -0.59 & -0.65 & 0.0039 & -0.19 & -0.30 & -0.45 \\
\hline 11 & 0.0017 & -0.21 & -0.28 & -0.31 & 0.0041 & -0.05 & -0.01 & -0.19 \\
\hline 12 & 0.0008 & -0.15 & -0.48 & -0.54 & 0.0030 & 0.04 & -0.19 & -0.21 \\
\hline 13 & -0.0010 & -0.28 & -0.84 & -0.93 & 0.0013 & -0.10 & -0.55 & -0.79 \\
\hline 14 & -0.0001 & -0.26 & -0.96 & -1.07 & 0.0034 & -0.02 & -0.68 & -0.82 \\
\hline 15 & 0.0014 & -0.09 & -0.93 & -1.04 & 0.0037 & 0.08 & -0.63 & -0.74 \\
\hline 16 & 0.0019 & 0.00 & -0.79 & -0.88 & 0.0039 & 0.15 & -0.62 & -0.66 \\
\hline 17 & 0.0040 & 0.85 & -0.70 & -0.66 & 0.0049 & 1.37 & -0.63 & -0.68 \\
\hline
\end{tabular}

* significant at $10 \% ;^{\$}$ significant at $5 \% ;{ }^{*}$ significant at $1 \%$ (two tailed test) 
Table 4: Average Abnormal Returns and Test Statistics Based on Dimson (1979) Betas for Chinese Acquiring Firms - Modes of Consideration

Abnormal Returns

\section{Patell Test}

Time AR-Cash AR-Alt

$\begin{array}{cc}0.0014 & 0.0006 \\ 0.0027 & -0.0026 \\ 0.0036 & 0.0020 \\ 0.0037 & 0.0037 \\ -0.0011 & 0.0046 \\ 0.0012 & 0.0020 \\ 0.0006 & 0.0092 \\ 0.0023 & 0.0026 \\ -0.0039 & 0.0036 \\ -0.0006 & 0.0024 \\ -0.0029 & -0.0018 \\ -0.0023 & -0.0017 \\ 0.0003 & 0.0087 \\ -0.0001 & 0.0006 \\ 0.0019 & -0.0057 \\ -0.0035 & -0.0113 \\ -0.0049 & -0.0034 \\ 0.0014 & 0.0063 \\ -0.0003 & 0.0021 \\ 0.0006 & -0.0082 \\ -0.0003 & 0.0002 \\ 0.0024 & 0.0071 \\ 0.0006 & -0.0008 \\ 0.0002 & -0.0039\end{array}$

$-0.04$
Corrado Test

Z-Diff

Z-Cash

Z-Alt

0.22
0.21

$\begin{array}{ll}0.22 & -0.22 \\ -0.62 & -0.32\end{array}$

$0.30 \quad 1.02$

$1.70^{*} \quad-0.28$

$-0.37$

1.16

$-0.90$

$-0.29$

$-0.70$

0.28

$$
-0.82
$$

$-0.99$

$-0.70$

$$
0.12
$$

$$
-0.37
$$$$
-0.21
$$$$
1.71^{*}
$$$$
0.11
$$

$-0.78$

$$
-1.07
$$$$
-0.21
$$$$
1.43
$$$$
-0.46
$$

0.10

0.40

0.29

0.76

$$
0.68
$$

$1.85^{\star}$

0.51

1.66 *

0.68

$-0.28$

0.04

$1.89^{*}$

$-0.29$

$-1.23$

$-1.60$

0.04

$2.12^{\#}$

$-0.10$

$-1.63$

$-0.53$

1.04

$-0.30$

$-0.99$
$-0.58$

1.35

$2.76^{\$}$

0.38

$-1.86^{*}$

$-1.80^{*}$

$-1.60$

$-0.87$

0.93

$-0.32$

0.81

$-1.83^{*}$

$-2.06^{\#}$

0.41

$-0.84$

0.00

$-0.70$

0.30

0.39

$-0.21$
$-0.21$

$-0.51$

1.40

$-0.95$

0.48

0.65

$-0.09$

$-2.49^{\$}$

$-1.75^{\star}$

$-0.94$

$-0.64$

$-0.68$

$-0.02$

1.44

$-0.16$

$-1.48$

$-1.21$

$-0.52$

1.15

$-0.12$

$-0.53$

0.49

0.55

Modified Corrado Test

Z-Cash Z-Alt Z-Diff

* significant at $10 \% ;{ }^{\$}$ significant at $5 \% ;{ }^{*}$ significant at $1 \%$ (two tailed test)

$\begin{array}{ccc}-0.14 & 0.13 & -0.20 \\ -0.69 & -0.34 & -0.25 \\ 0.34 & 1.09 & -0.53 \\ 1.90^{*} & -0.29 & 1.55 \\ -0.64 & 0.82 & -1.03 \\ 1.52 & 0.73 & 0.56 \\ 2.54^{\$} & 1.67^{*} & 0.62 \\ 0.42 & 0.54 & -0.08 \\ -2.07^{\#} & 1.78^{*} & -2.72^{\$} \\ -2.01^{\#} & 0.73 & -1.93^{*} \\ -1.79^{*} & -0.29 & -1.06 \\ -0.97 & 0.05 & -0.72 \\ 1.04 & 2.01^{\#} & -0.69 \\ -0.35 & -0.30 & -0.04 \\ 0.91 & -1.31 & 1.57 \\ -2.05^{\#} & -1.71^{*} & -0.24 \\ -2.29^{\#} & 0.05 & -1.65^{\star} \\ 0.46 & 2.26^{\#} & -1.27 \\ -0.94 & -0.10 & -0.59 \\ 0.00 & -1.73^{*} & 1.23 \\ -0.78 & -0.56 & -0.16 \\ 0.33 & 1.11 & -0.55 \\ 0.44 & -0.32 & 0.53 \\ -0.21 & -0.80 & 0.42\end{array}$

0.42 
$\begin{array}{ccc}\text { Table 5: Cumulative Average Abnormal Returns and Test Statistics Based on Dimson (1979) Betas for Chinese Acquirers - Modes of Consideration } \\ \text { CAARs } & \text { Patell Test } & \text { Corrado Test }\end{array}$

\begin{tabular}{|c|c|c|c|c|c|c|c|c|c|c|c|}
\hline \multirow[b]{2}{*}{ Time } & \multicolumn{2}{|c|}{$\begin{array}{c}\text { CAARs } \\
\end{array}$} & \multicolumn{3}{|c|}{ Patell Test } & \multicolumn{3}{|c|}{ Corrado Test } & \multicolumn{3}{|c|}{ Modified Corrado Test } \\
\hline & CAR-Cash & CAR-Alt & t-Cash & t-Alt & Z-Diff & Z-Cash & Z-Alt & Z-Diff & Z-Cash & Z-Alt & Z-Diff \\
\hline-6 & 0.0014 & 0.0006 & 0.53 & 0.24 & 0.21 & 1.00 & -0.22 & 0.86 & -0.11 & 0.13 & -0.17 \\
\hline-5 & 0.0041 & -0.0020 & 0.24 & -0.44 & 0.47 & 0.56 & -0.38 & 0.66 & -0.62 & -0.34 & -0.20 \\
\hline-4 & 0.0077 & -0.0001 & 0.76 & 0.67 & 0.06 & 0.63 & 0.28 & 0.25 & -0.29 & 0.43 & -0.51 \\
\hline-3 & 0.0114 & 0.0036 & 1.29 & 0.52 & 0.54 & 1.27 & 0.10 & 0.83 & 0.75 & 0.31 & 0.31 \\
\hline-2 & 0.0104 & 0.0083 & 1.07 & 0.96 & 0.07 & 0.96 & 0.43 & 0.37 & 0.32 & 0.65 & -0.23 \\
\hline-1 & 0.0115 & 0.0103 & 1.17 & 1.22 & -0.04 & 1.37 & 0.67 & 0.50 & 0.96 & 0.91 & 0.04 \\
\hline 0 & 0.0121 & 0.0195 & 0.51 & 1.41 & -0.63 & $2.22^{\#}$ & 1.32 & 0.63 & 0.70 & 1.16 & -0.32 \\
\hline 1 & 0.0144 & 0.0221 & $1.70^{*}$ & 1.62 & 0.05 & $2.22^{\#}$ & 1.41 & 0.57 & $1.89^{*}$ & 1.54 & 0.25 \\
\hline 2 & 0.0106 & 0.0257 & 1.13 & 1.24 & -0.08 & 1.56 & $1.87^{*}$ & -0.23 & 1.05 & $2.08^{\#}$ & -0.73 \\
\hline 3 & 0.0100 & 0.0280 & 0.65 & 0.86 & -0.15 & 0.97 & $2.00^{\#}$ & -0.73 & 0.32 & $2.20^{\#}$ & -1.33 \\
\hline 4 & 0.0071 & 0.0262 & 0.20 & 0.50 & -0.21 & 0.49 & $1.83^{*}$ & -0.95 & -0.29 & $2.00^{\#}$ & -1.62 \\
\hline 5 & 0.0047 & 0.0245 & 0.07 & 0.31 & -0.17 & 0.24 & $1.76^{*}$ & -1.08 & -0.57 & $1.94^{*}$ & $-1.77^{*}$ \\
\hline 6 & 0.0050 & 0.0332 & 0.16 & 0.45 & -0.20 & 0.47 & $2.22^{\#}$ & -1.23 & -0.24 & $2.45^{\#}$ & $-1.91^{*}$ \\
\hline 7 & 0.0049 & 0.0338 & 0.08 & 0.42 & -0.24 & 0.38 & $2.06^{\#}$ & -1.19 & -0.36 & $2.28^{\#}$ & $-1.86^{*}$ \\
\hline 8 & 0.0068 & 0.0281 & 0.39 & 0.20 & 0.13 & 0.56 & $1.67^{*}$ & -0.79 & -0.11 & $1.84^{*}$ & -1.38 \\
\hline 9 & 0.0033 & 0.0168 & -0.14 & -0.13 & -0.01 & 0.11 & 1.22 & -0.78 & -0.65 & 1.34 & -1.40 \\
\hline 10 & -0.0016 & 0.0134 & -0.56 & -0.22 & -0.24 & -0.36 & 1.19 & -1.10 & -1.23 & 1.32 & $-1.80^{*}$ \\
\hline 11 & -0.0002 & 0.0197 & -0.42 & -0.05 & -0.27 & -0.26 & $1.66^{*}$ & -1.36 & -1.07 & $1.84^{*}$ & $-2.06^{\#}$ \\
\hline 12 & -0.0005 & 0.0218 & -0.36 & 0.01 & -0.26 & -0.44 & 1.59 & -1.43 & -1.28 & $1.77^{*}$ & $-2.15^{\#}$ \\
\hline 13 & 0.0000 & 0.0137 & -0.23 & -0.13 & -0.07 & -0.43 & 1.18 & -1.14 & -1.25 & 1.31 & $-1.81^{*}$ \\
\hline 14 & -0.0003 & 0.0139 & -0.27 & -0.09 & -0.13 & -0.56 & 1.04 & -1.14 & -1.41 & 1.15 & $-1.81^{*}$ \\
\hline 15 & 0.0021 & 0.0210 & 0.04 & 0.03 & 0.01 & -0.49 & 1.24 & -1.22 & -1.31 & 1.38 & $-1.90^{*}$ \\
\hline 16 & 0.0027 & 0.0201 & 0.12 & 0.02 & 0.07 & -0.40 & 1.15 & -1.10 & -1.18 & 1.28 & $-1.74^{*}$ \\
\hline 17 & 0.0029 & 0.0162 & 0.43 & $2.54^{\$}$ & -1.49 & -0.44 & 0.92 & -0.96 & -0.75 & $2.59^{\$}$ & $-2.36^{\#}$ \\
\hline
\end{tabular}


Table 6: Simple Logit Regressions

\begin{tabular}{|c|c|c|c|}
\hline $\begin{array}{l}\text { Independent } \\
\text { Variable }\end{array}$ & Coefficient & z-Statistic & p-val \\
\hline EP log difference & -0.354 & -2.91 & $0.00^{\$}$ \\
\hline $\begin{array}{l}\text { EP log difference } \\
\text { RANK }\end{array}$ & 0.007 & 2.89 & $0.00^{\$}$ \\
\hline $\begin{array}{c}\text { Over_Val_MED (log } \\
\text { difference) }\end{array}$ & 0.703 & 1.91 & $0.06^{*}$ \\
\hline $\begin{array}{c}\text { Over_Val_33 } \\
\text { (log difference) }\end{array}$ & 1.079 & 2.95 & $0.00^{\$}$ \\
\hline Over_Val_MED_BM1 & 2.136 & 3.76 & $0.00^{\$}$ \\
\hline Over_Val_MED_BM2 & 2.105 & 3.71 & $0.00^{\$}$ \\
\hline Over_Val_33_BM1 & 1.564 & 3.59 & $0.00^{\$}$ \\
\hline Over_Val_33_BM2 & 1.564 & 3.59 & $0.00^{\$}$ \\
\hline
\end{tabular}

Notes: This table reports results for a logit regression of a single explanatory variable:

$$
D_{M}=a+b X+u
$$

where the dependent variable $D_{M}$ is a dummy variable that is 0 if the mode of consideration is cash and 1 if an alternative mode of consideration is used and the $X$ variable, is listed in Column 1. EP log difference is the market adjusted log EP ratio; that is, the log of 0.001 plus EP ratio minus the log of 0.001 plus EP ratio of the market. EP log difference RANK is simply the rank of firms by EP log difference. Results in the bottom half of the table are based on dummy variables that are 1 if the acquiring firm is over-valued and 0 otherwise. We use two thresholds. Over_Val_MED (log difference) is 1 if the market-adjusted log earnings-price ratio is below the median and Over_Val_33 (log difference) is 1 if the market-adjusted log earnings-price ratio is below the $33^{\text {rd }}$ percentile. We then construct measures on using bookmarket ratio (BM) in a similar way. BM1 is calculated using the equally-weighted average book-market ratio as the benchmark while BM2 using the median book-market ratio as the benchmark. Thus Over_Val_MED_BM1 is 1 if the book-market ratio adjusted using the equally weighted market average is below the median of our acquirers sample.

Over_Val_33_BM2 is 1 if the book-market ratio adjusted using the market median is below the $33^{\text {rd }}$ percentile of our acquirers sample. ${ }^{*}$ is statistically significant at the $10 \%$ level and ${ }^{\$}$ is statistically significant at the $5 \%$ level. 


\section{Table 7: Mann-Whitney Tests}

Panel A: Full Sample Independent

Over-valuation

Variable

$$
\text { Variable }
$$

z-Statistic

p-Val

CAAR(-1,+2)

None

$-2.307$

$0.021^{\$}$

CAAR(-6,+17)

None

$-1.646$

0.100 *

Panel B: Over-valued Sample Independent

Over-valuation Variable Variable

Z-Statistic

p-Val

CAAR(-1,+2)

CAAR(-1,+2)

CAAR $(-1,+2)$

CAAR $(-6,+17)$

CAAR $(-6,+17)$

CAAR(-6,+17)

$\begin{array}{ccc}\text { Over_Val_MED } & -2.321 & \mathbf{0 . 0 2 0}^{\$} \\ \text { Over_Val_MED_BM1 } & -2.982 & \mathbf{0 . 0 0 3}^{\$} \\ \text { Over_Val_MED_BM2 } & -2.989 & \mathbf{0 . 0 0 3 ^ { \$ }} \\ \text { Over_Val_MED } & -2.211 & \mathbf{0 . 0 2 7 ^ { \$ }} \\ \text { Over_Val_MED_BM1 } & -1.996 & \mathbf{0 . 0 4 6 ^ { \$ }} \\ \text { Over_Val_MED_BM2 } & -2.110 & \mathbf{0 . 0 3 5 ^ { \$ }}\end{array}$

\section{Over-valuation Variable}

$\begin{array}{ccc}\text { Over_Val_33 } & -2.122 & \mathbf{0 . 0 3 4 ^ { \$ }} \\ \text { Over_Val_33_BM1 } & -3.062 & \mathbf{0 . 0 0 2}^{\$} \\ \text { Over_Val_33_BM2 } & -2.816 & \mathbf{0 . 0 0 5 ^ { \$ }} \\ \text { Over_Val_33 } & -1.925 & \mathbf{0 . 0 5 4}^{\star} \\ \text { Over_Val_33_BM1 } & -2.473 & \mathbf{0 . 0 1 3}^{\$} \\ \text { Over_Val_33_BM2 } & -2.303 & \mathbf{0 . 0 2 1}^{\$}\end{array}$

Panel C: Not over-valued Sample Independent

\section{Over-valuation} Variable

CAAR(-1,+2)
CAAR(-1,+2)
CAAR(-1,+2)
CAAR(-6,+17)
CAAR(-6,+17)
CAAR(-6,+17)

$\begin{array}{cc}\text { Over_Val_MED } & -1.599 \\ \text { Over_Val_MED_BM1 } & -0.340 \\ \text { Over_Val_MED_BM2 } & -0.323 \\ \text { Over_Val_MED } & -0.427 \\ \text { Over_Val_MED_BM1 } & -0.276 \\ \text { Over_Val_MED_BM2 } & -0.258\end{array}$

p-Val

0.110

0.734

0.747

0.669

0.782

0.796

\section{Over-valuation} Variable

$\begin{array}{ccc}\text { Over_Val_33 } & -1.625 & 0.104 \\ \text { Over_Val_33_BM1 } & -0.998 & 0.318 \\ \text { Over_Val_33_BM2 } & -1.095 & 0.274 \\ \text { Over_Val_33 } & -0.757 & 0.449 \\ \text { Over_Val_33_BM1 } & -0.804 & 0.421 \\ \text { Over_Val_33_BM2 } & -0.872 & 0.383\end{array}$

Notes: these are Mann-Whitney tests conducted on the ranked sum of the Cumulative Average Abnormal Returns as given in the Independent Variable column. These are grouped by the mode of consideration dummy variable, $D_{M}$, which is 0 if the mode of consideration is pure cash and 1 for alternative modes of consideration. Panel A reports results for the full sample. Panel B reports results for the over-valued sample and Panel $\mathrm{C}$ reports results for the not over-valued sample. Overvaluation is measured by the market-adjusted log earnings-price ratio or log book-market ratio; Over Val Med uses the median as the cut-off point and Over_Val_33 uses the $33^{\text {rd }}$ percentile as the cut-off point. 
Figure 1: Average Abnormal Returns Across N = 279 Chinese Acquiring Firms with A Shares on issue and Covering the Period from 1 January, 1990 until 31 December, 2008

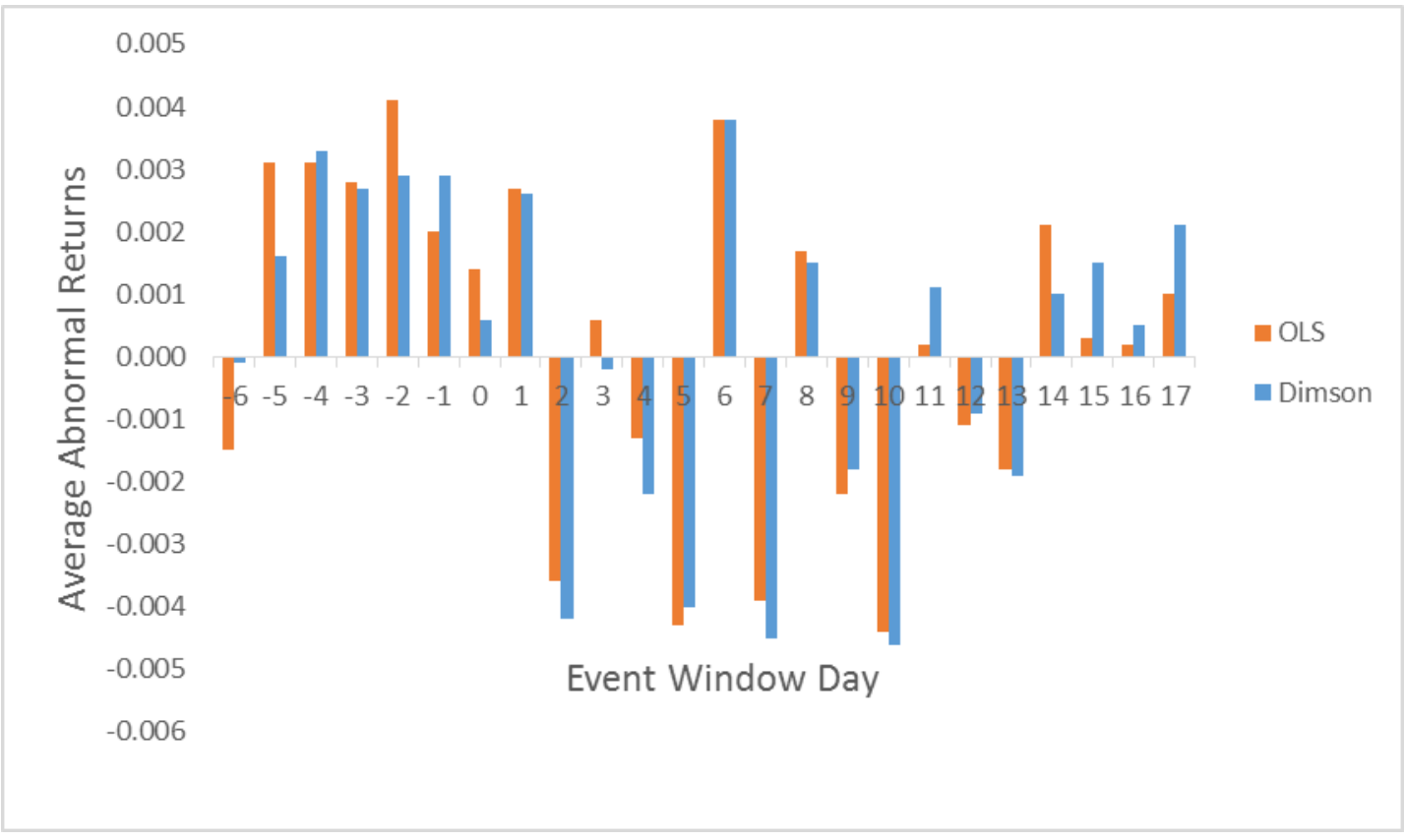

Figure 2: Cumulative Average Abnormal Returns Across N = 279 Chinese Acquiring Firms with A Shares on issue and Covering the Period from 1 January, 1990 until 31 December, $\underline{2008}$

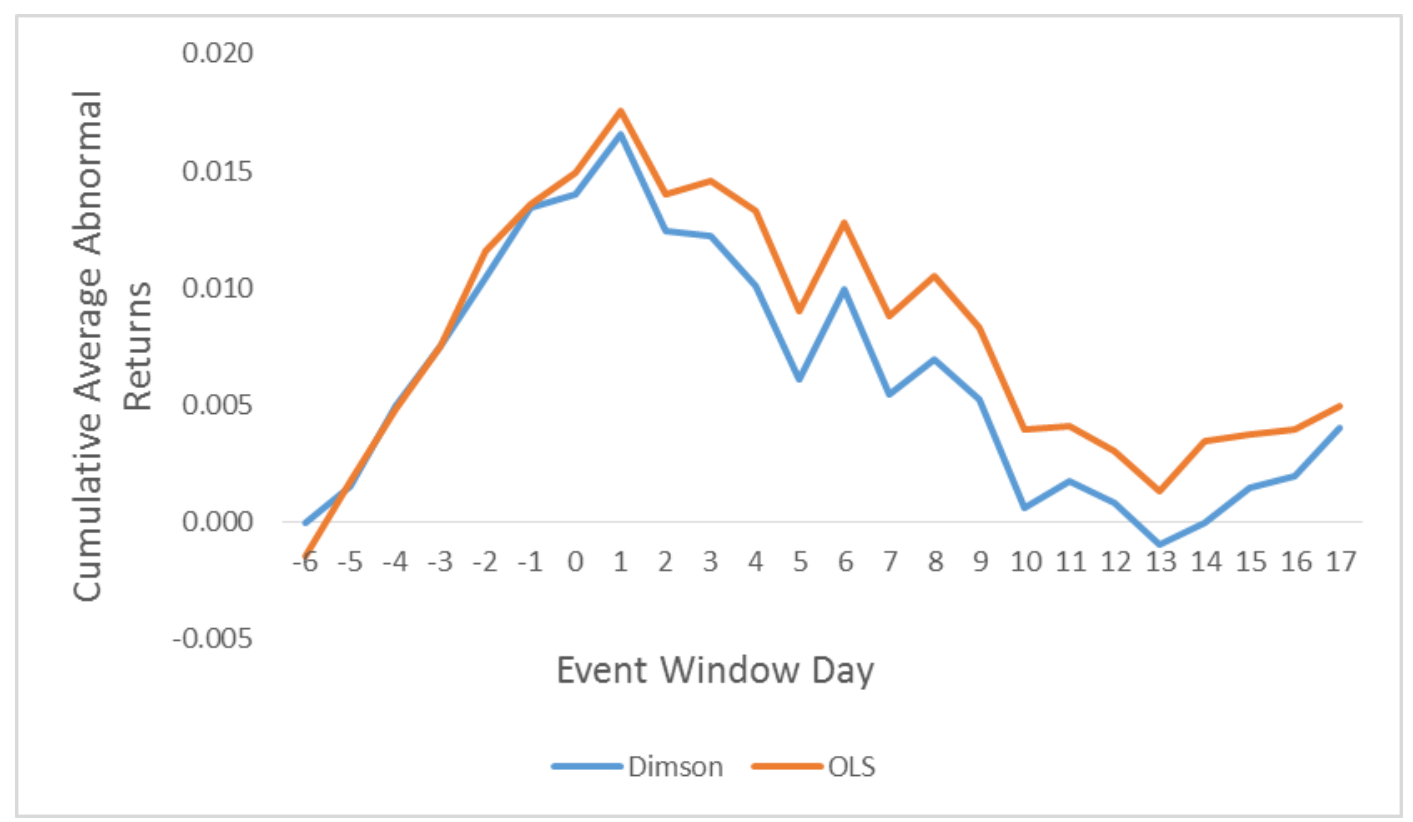


Figure 3: Average Abnormal Returns Based on Dimson (1979) Betas for Chinese Acquiring Firms over the Period from 1 January, 1990 until 31 December, 2008 for Cash (N = 168) as against Alternative $(M=45)$ Modes of Consideration

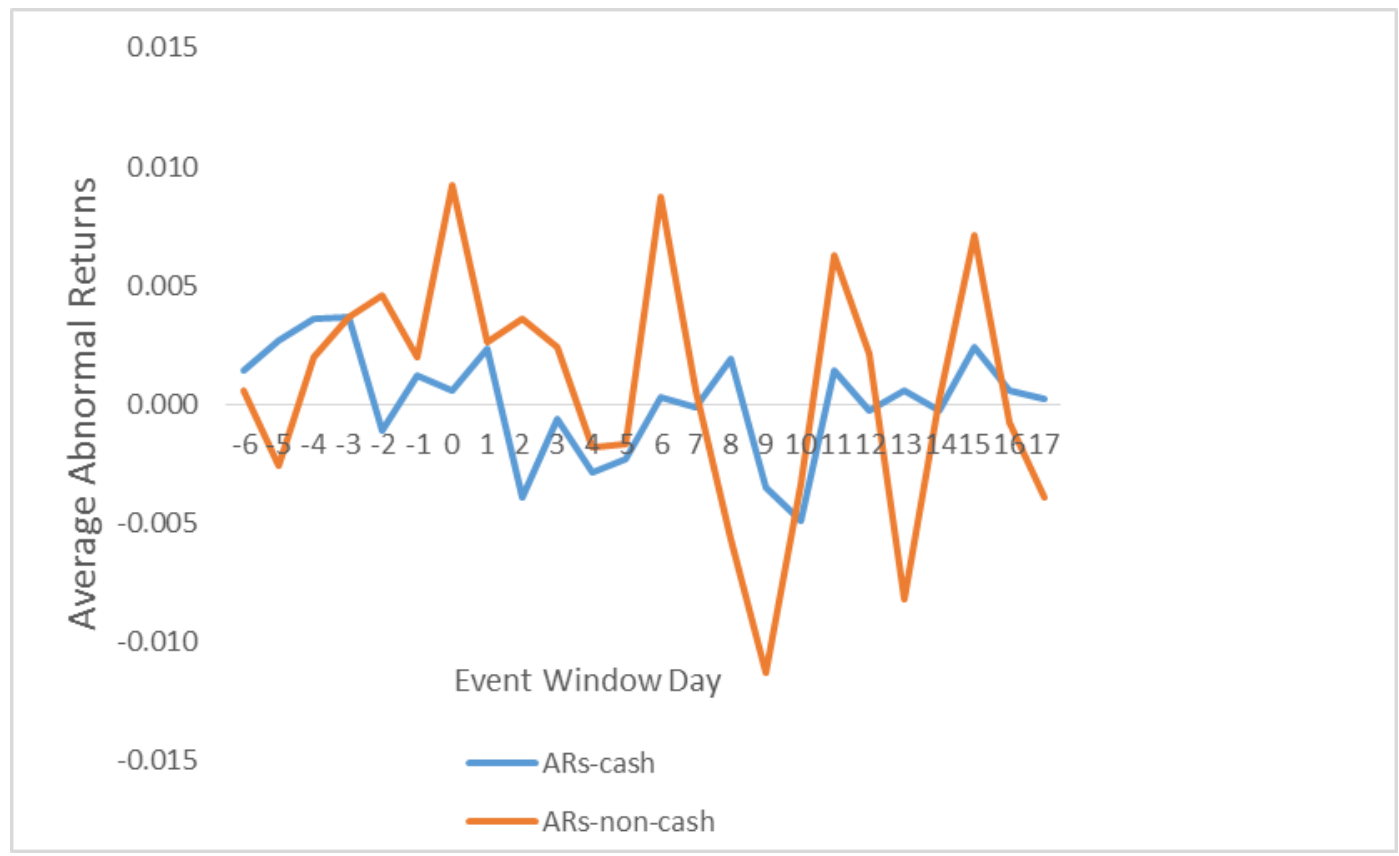

Figure 4: Cumulative Average Abnormal Returns Based on Dimson (1979) Betas for Chinese Acquiring Firms over the Period from 1 January, 1990 until 31 December, 2008 for Cash $(N=168)$ as against Alternative $(M=45)$ Modes of Consideration

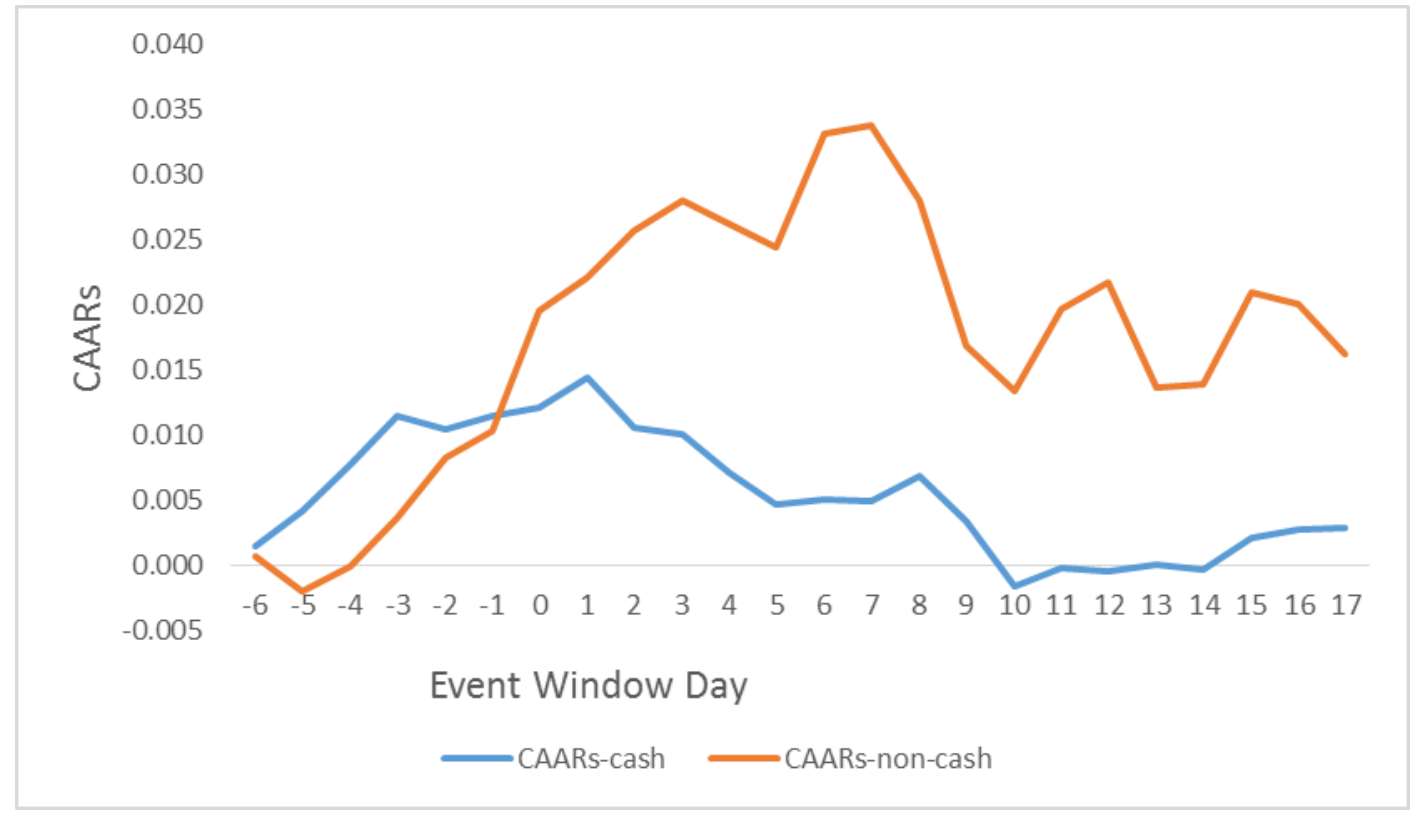




\section{Appendix Table B.6: Logit Regressions including control variables}

\section{Independent Variable}

EP log difference

EP log difference RANK

Over_Val_MED (log

Over_Val_33

(log difference)

Over_Val_MED_BM1

Over_Val_MED_BM2

Over_Val_33_BM1

Over_Val_33_BM2
Coefficient

$-0.443$

0.011

0.993

1.444

2.448

2.396

1.651

1.657
z-Statistic p-val

$0.01^{\$}$

$0.00^{\$}$

$0.05^{\$}$

$0.00^{\$}$

$0.00^{\$}$

$0.00^{\$}$

$0.00^{\$}$

$0.00^{\$}$

Notes: This table reports results for the following logit regression:

$$
D_{M}=a+b X+\sum_{i=1}^{l} \delta_{i} Z_{i}+u
$$

where the dependent variable $D_{M}$ is a dummy variable that is 0 if the mode of consideration is cash and 1 if the mode of consideration is an alternative mode of consideration. The $X$ variable, is listed in Column 1 and the $Z$ variables are i) cash reserves to book value, ii) operating margin and iii) log of the market value. EP log difference is the market adjusted log EP ratio; that is, the log of 0.001 plus EP ratio minus the log of 0.001 plus EP ratio of the market. EP log difference RANK is simply the rank of firms by EP log difference. Results in the bottom half of the table are based on dummy variables that are 1 if the acquiring firm is over-valued and 0 otherwise. We use two thresholds. Over_Val_MED (log difference) is 1 if the market-adjusted log earnings-price ratio is below the median and Over_Val_33 (log difference) is 1 if the market-adjusted log earnings-price ratio is below the $33^{\text {rd }}$ percentile. We then construct measures on using book-market ratio (BM) in a similar way. BM1 is calculated using the equally-weighted average book-market ratio as the benchmark while BM2 using the median book-market ratio as the benchmark. Thus Over_Val_MED_BM1 is 1 if the bookmarket ratio adjusted using the equally weighted market average is below the median of our acquirers sample. Over_Val_33_BM2 is 1 if the book-market ratio adjusted using the market median is below the $33^{\text {rd }}$ percentile of our acquirers sample. * is statistically significant at the $10 \%$ level and ${ }^{\$}$ is statistically significant at the $5 \%$ level. 